\title{
Resistivity mapping as a tool for identification and characterisation of weakness zones in crystalline bedrock: definition and testing of an interpretational model
}

\author{
Jan Steinar Rønning • Guri V. Ganerød • \\ Einar Dalsegg • Fabienne Reiser
}

Received: 25 June 2013/Accepted: 18 November 2013/Published online: 21 December 2013

(C) The Author(s) 2013. This article is published with open access at Springerlink.com

\begin{abstract}
In recent years, the focus on feasibility studies for tunnels has increased in Norway. Traditionally, the refraction seismic method and the very low-frequency electromagnetic method (VLF-EM) have been used. The Geological Survey of Norway introduced the electrical resistivity traversing method (ERT) in feasibility studies for tunnel construction purposes. Resistivity modelling shows that the method has the potential to characterise fracture zones geometrically; i.e., the thickness, dip, and depth extent. Based on previous studies, a model for mineralogical characterisation is proposed. This model, and the possibility for geometrical characterisation, is critically tested with success on three tunnel projects. The results of the comparison study, with regards to weakness zones, show that VLF-EM is a method that is capable of locating fracture zones, while refraction seismic is capable of locating and indicating the width of the zone, and can be used to imply the thickness of the soil cover above bedrock. The $2 \mathrm{D}$ resistivity method is able to locate the weakness zone, indicate the width, depth extent, and the dip of the zone, and in addition, characterise the zone with respect to stability or water problems. The crystalline bedrock characterisation is divided into three groups: resistivity values above $3,000 \Omega \mathrm{m}$ indicating good rock quality, values between 3,000 and $500 \Omega \mathrm{m}$ indicating bedrock with mainly water problems, while values $<500 \Omega$ m indicate clay-bearing, unstable rock with fewer
\end{abstract}

J. S. Rønning · G. V. Ganerød ( () ) E. Dalsegg · F. Reiser Geological Survey of Norway (NGU), Post-Box 6315, Sluppen, 7491 Trondheim, Norway

e-mail: guri.ganerod@ngu.no

\section{J. S. Rønning}

Norwegian University of Science and Technology (NTNU),

7491 Trondheim, Norway water problems. From our investigations, we conclude that the $2 \mathrm{D}$ resistivity method is a very good supplement to traditional methods for feasibility studies on tunnelling purposes in crystalline rock.

Keywords Resistivity method (ERT) - Identification and characterisation - Weakness zone in crystalline rock . Geophysical mapping $\cdot$ Feasibility studies $\cdot$ Tunnels

Résumé En Norvège, au cours des dernières années, l'accent a été mis sur les études de faisabilité pour la construction de tunnels. Traditionnellement, la méthode de sismique réfraction et à très basse fréquence électromagnétique (VLF-EM, Very Low Frequency Electro Magnetic Method) est utilisée. Le Bureau de Recherches Géologiques de Norvège (NGU, Norwegian Geological Survey) a présenté la méthode de résistivité électrique traversante (ERT, Electrical Resistivity Traversing method) dans des études de faisabilité. La modélisation de la résistivité montre que la méthode a le potentiel de caractériser la géométrie des zones de fracture, c'est à dire l'épaisseur, le pendage et l'extension en profondeur des failles. Sur la base de ces études, un modèle pour la caractérisation minéralogique est proposé. Ce modèle, ainsi que la possibilité de caractérisation géométrique, a été testé avec succès sur trois projets de tunnels. En ce qui concerne les zones de faiblesse, les résultats de l'étude comparative montrent que la méthode VLF-EM est capable de localiser les zones de fracture, et que la méthode de sismique réfraction est capable de localiser et d'indiquer la largeur de la zone. Cette approche peut être utilisée pour déterminer l'épaisseur de la couverture au-dessus du socle. La méthode de résistivité $2 \mathrm{D}$ est capable de localiser la zone de faiblesse, d'indiquer la largeur, la profondeur et le pendage de la zone, et peut également caractériser la zone en termes de 
stabilité ou de problèmes liés a l'eau. La caractérisation du socle cristallin est divisée en trois groupes: les valeurs de résistivité au-dessus de $3000 \mathrm{ohm}$.m indiquent une bonne qualité de roche, des valeurs comprises entre 3000 et 500 ohm.m caractérisent un socle avec des problèmes de l'eau, tandis que des valeurs inférieures à 500 ohm.m indiquent la présence d'une roche argileuse instable, avec moins de problèmes d'eau. Nos études montrent que la méthode de résistivité $2 \mathrm{D}$ est un très bon complément aux méthodes traditionnelles pour les études de faisabilité de construction de tunnel dans une roche cristalline.

Mots clés méthode de résistivité (ERT) - identification et caractérisation - zone de faiblesse dans la roche cristalline $\cdot$ cartographie géophysique études de faisabilité · tunnels

\section{Introduction}

Each year, more than $30 \mathrm{~km}$ of road and railroad tunnels in bedrock are constructed in Norway. Normally this is done without any impact on the surrounding environment and within economical budgets, however, over the years a number of tunnelling projects have encountered significant problems. Such problems include encountering zones with major water leakage and substantial volumes of unstable rocks, resulting in extensive delays and considerable overspending during tunnel construction. Therefore, an increased emphasis on site investigations for tunnel projects has been critical in recent years. Studies such as the research and development project "Tunnels for the Citizens" in 2001-2003 (Karlsrud et al. 2003; Palmstrøm et al. 2003; Rønning 2003; Lindstrøm and Kveen 2004) have concluded that site investigations are important and that further work addressing the extent and content of such studies are required.

The Geological Survey of Norway (NGU) was involved in the feasibility studies for tunnelling projects, with special focus on geophysical methods for mapping the subsurface. Here, the $2 \mathrm{D}$ resistivity method or earth resistivity traversing (ERT) was introduced as an alternative to the more traditional methods, such as refraction seismic and VLF-EM (very low-frequency electromagnetic, Rønning 2003; Rønning et al. 2003). The idea behind using the resistivity method is that fractured rocks are more porous and contain more water than the undisturbed host rock, resulting in a reduced electrical resistivity. In addition, the presence of clay minerals may reduce the resistivity further. One of the case studies in this project was the Lunner tunnel, Rv 35 in Oppland County (Fig. 1), which proved to be a success with respect to the $2 \mathrm{D}$ resistivity method as a supplement to traditional geophysical methods.
The concept of the characterisation model that is presented here, and that is valid for crystalline rock, is that resistivity values of $3,000 \Omega \mathrm{m}$ and higher indicate good rock mass, zones with resistivity values from 3,000 to $500 \Omega \mathrm{m}$ indicate potentially high water leakage, while zones with resistivity values lower than $500 \Omega$ m indicate areas of instability with potential clay filling, but less water leakage. Following the Lunner tunnel project, NGU performed resistivity modelling to establish the possibilities and limitations regarding the resistivity method, especially with respect to characterising weakness zones in bedrock (Reiser et al. 2009; Rønning et al. 2009a). The result of the modelling shows that the $2 \mathrm{D}$ resistivity method is able to correctly indicate the width of the zone close to the surface, the dip direction, and the depth extent of the weakness zone. Therefore, one major conclusion is that the resistivity method is able to identify weakness zones in crystalline bedrock, as well as give a geometric and mineralogical characterisation of zones.

The main disadvantages of the method are that thick overburden, especially containing marine clay, prohibits the current from penetrating into the bedrock. The penetration depth depends on the length of the electrode spread, and the resolution will decrease with depth. As with all other geophysical methods, a contrast in petrophysical properties is necessary. All these effects reduce the possibility to map fracture zones in the subsurface, and modelling has shown that artificial effects, such as a widening of the zone with increasing depth, disproportionate resistivity values in the fracture zone, and artificial anomalies outside the fracture zone may occur in the measured data (Reiser et al. 2009). Similar studies have also been carried out for the Viggja and Storsand tunnels at E 39 in SørTrøndelag County, Norway (Ganerød et al. 2006; Ødegaard 2006).

The resistivity model for characterising weakness zones described in this paper has been tested on three additional tunnel projects in Norway: the Hanekleiv tunnel located along highway E18 in Vestfold County, the Vadfoss tunnel located on Rv 38 near Kragerø in Telemark County, and the Ravneheia tunnel located on Rv 465, close to Farsund in Vest-Agder County (Fig. 1).

\section{Geophysical methods}

Resistivity is an electrical method that was developed in the early 1900s, but first became widely applied in hydrogeology and water pollution studies in the 1970s (Reynolds 1997). In recent years, the method has been further developed, especially with respect to field procedures and inversion for 2D and 3D application (Dahlin 1993; Loke and Barker 1996a, b). In our study, we used the 

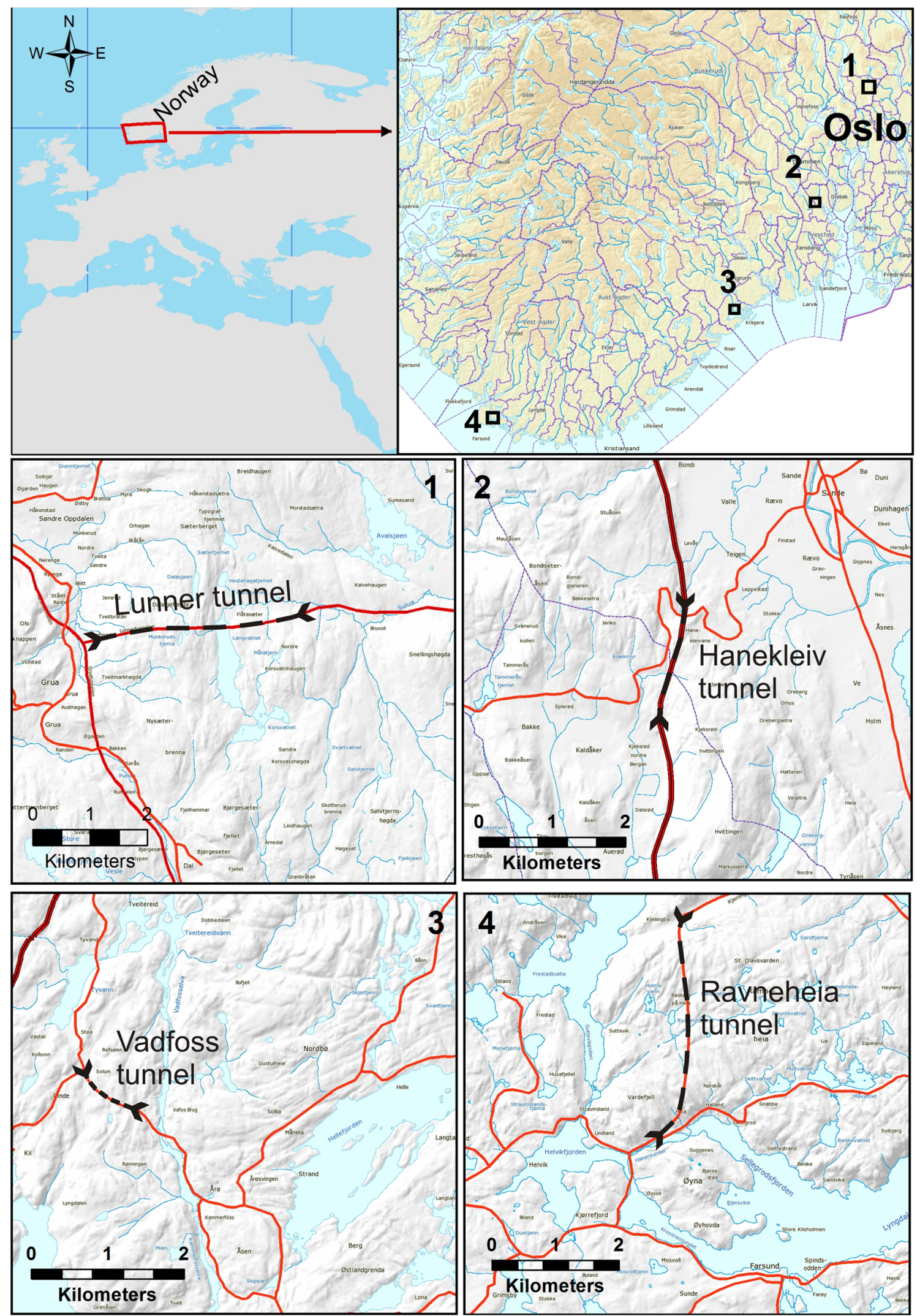

Fig. 1 All four tunnels described in this study are located in southern Norway. The Lunner tunnel is located on Rv 35 in the Lunner municipality, Oppland County, the Hanekleiv tunnel is located along

highway E18 in Vestfold County, the Vadfoss tunnel is located on Rv 38 near Kragerø in Telemark County, and the Ravneheia tunnel is located on Rv 465, close to Farsund in Vest-Agder County 
Lund system for resistivity profiling (Dahlin 1993). This system consists of four cables, each 100 or $200 \mathrm{~m}$ in length, which are connected to steel electrodes in the soil cover. The Lund system works with 81 electrodes, but in a standard spread we use every second electrode at the end cables, which means 61 electrodes are used for each array. Normally, we use an electrode spacing of 5 or $10 \mathrm{~m}$, which results in a maximum penetration depth of 60 or $120 \mathrm{~m}$, respectively. The electrode configurations used for the field measurements presented are Wenner (Lunner tunnel) and Gradient (Rønning et al. 2009b).

The resistivity method measures apparent resistivity (in $\Omega \mathrm{m}$ ) in the subsurface, which is a weighted average of resistivity values of the influential volume (Reynolds 1997; Dahlin 1993). To obtain "true" resistivity, a conceptual model with cells of a given resistivity value is made and inverted into a resistivity profile (Loke and Barker 1996a). When the result of the inverted profile matches the measured data, a more representative resistivity of the subsurface is shown. Low resistivity (blue colours in our diagrams), is caused by groundwater or clay content in fracture and/or fault zones, whereas high resistivity (red colours) reflects good, massive, undisturbed rock. Standard inversion is applied on the collected data using Res2DInv (Loke 2002). For this application a vertical-/horizontal filter $=2$ is used, which favours vertical structures (Reiser et al. 2009).

Seismic refraction records the travel time of acoustic $P$ waves in the subsurface (Reynolds 1997), which propagate with the elasticity of the material. The range of the seismic velocity is from $200 \mathrm{~m} / \mathrm{s}$ (loose sand) up to above $6,000 \mathrm{~m} /$ s (dense crystalline rock, Reynolds 1997). Fractured rock and fault zones will commonly have a lower wave velocity than intact bedrock (Reynolds 1997). The seismic refraction method can also be used to describe rock quality (Barton 2007). In this study, seismic profiling was carried out with a line of 24 geophones, a geophone spacing of 5 metres, a shot interval of 27.5 metres, and with dynamite as the source for the seismic signal (Rønning et al. 2009b).

VLF-EM (very low-frequency electromagnetic) is a cheap and rapid tool for reconnaissance mapping of electrical conductive structures, commonly identifying mineralised bodies and water-bearing features (Reynolds 1997; Paterson and Ronka 1971). VLF transmission is primarily used by military communication, with VLF transmitters distributed around the world (most located in Europe and North America). The transmitters send out a powerful electromagnetic wave, which propagates outward horizontally. If electrical conductive material is present in the subsurface, secondary currents are induced, and the total magnetic field is no longer horizontal. By measuring the dip of the total magnetic field and an imaginary component, which is dependent on the conductivity contrast, information of conductive zones can be achieved. When data are acquired, the survey profile is executed along the magnetic component of the transmitted electromagnetic field. A major drawback with this method is that the VLF data acquisition is totally dependent on appropriate transmitter coverage in the survey area. The transmitters are occasionally turned off; in such cases, no signals are available. In Norway, there is a limited coverage of transmitters, restricting the use of VLF in certain areas and directions. Further more, topography has an effect on VLF efficacy, and the system is also highly sensitive to electrical infrastructure, such as power lines (Reynolds 1997). The VLF data was obtained with a $20-\mathrm{m}$ interval, and a $10-\mathrm{m}$ interval above anomalies (Rønning et al. 2009b).

The AMAGER-method (AeroMAgnetic and GEomorphological Relations) is used for mapping the occurrence of zones with deep weathering in the bedrock (Olesen et al. 2007). This method combines aeromagnetic data and topographic/bathymetric data to enhance structures with low magnetic anomalies, which are interpreted to contain magnetically depleted rock, such as weathered rocks that have resulted in clay-rich zones. These large clay-filled zones are considered to be deep weathering from subtropical conditions in Norway during late the Triassic to Early Cretaceous (i.e., 200-145 Ma, Olesen et al. 2007). Topographic data, in the scale of 1:5.000 and 1:10.000, was combined with bathymetry, from a multi-beam echosounder instrument. Aeromagnetic data was acquired from helicopter and aeroplane surveillance, with line spacing from 200 to $250 \mathrm{~m}$ and an altitude from 60 to $100 \mathrm{~m}$ above sea level. The datasets were filtered using a technique to enhance the magnetic signals from zones that exhibited low magnetic anomaly and/or topographic/bathymetric depression (Olesen et al. 2007).

\section{Resistivity modelling}

To explore the possibilities and limitations connected to the resistivity method, we have carried out model experiments. The modelling is conducted in four stages, where the first stage involves making the required model of cells and assigning the different cells a specific resistivity value. Then, synthetic data of the model is forward calculated (Dahlin and Zhou 2004), giving synthetic data that are equivalent to the data measured in the field. In order to simulate natural conditions, $5 \%$ ambient noise was added to the data. The final and critical stage is the inversion, where a physical model is inverted from the synthetic data. Following this procedure, the inverted model should resemble the initial synthetic model. Deviations are caused by weaknesses in the inversion procedure and/or methodological limitations such as resolution. Synthetic data is 
calculated using the program Res2DMod (Loke 2002), and the inversion of these data are performed for Wenner, gradient, dipole-dipole and pole-dipole electrode configurations using the software Res2DInv (Loke 2007).

In the modelling, we have used geological parameters commonly found in Norwegian soil cover and bedrock. The initial model is a 10 -m-thick vertically-fractured zone with a depth extent of $150 \mathrm{~m}$ in host rock and resistivity of $5,000 \Omega \mathrm{m}$, representing massive crystalline bedrock. The resistivity in the vertical zone is $500 \Omega \mathrm{m}$, representing a fracture zone containing clay (see examples in Figs. 2, 3, 4). From this standard model, we have varied fracture-zone thickness $(5,10,20$ and 40 m, Fig. 2), fracture-zone depth extent (20, 40, 80 and 150 m, Fig. 3) and fracture-zone dip $\left(90,75.60\right.$ and $30^{\circ}$, Fig. 4). In addition, we have varied the resistivity contrast, the soil-cover thickness $(0,5,10,20$ and $40 \mathrm{~m})$, and composition. Soil-cover resistivity of $500 \Omega \mathrm{m}$ represents coarse-grained sediments (sand/gravel or moraine); $100 \Omega \mathrm{m}$ represents fine-grained sediments, water-saturated sand or silt; $50 \Omega \mathrm{m}$ represents leached sediments (e.g., quick clay), and $10 \Omega$-m represents unbleached-salt marine clay (Solberg et al. 2008, 2011).

\section{Modelling with different electrode configurations}

To examine the surveying efficiency and imaging capabilities, Dahlin and Zhou (2004) used ten electrode configurations on five synthetic geological models. They concluded that the Gradient, pole-dipole, dipole-dipole and Schlumberger-Wenner configurations are strongly recommended for 2D resistivity imaging. Since the Wenner configuration was commonly used when we started our resistivity imaging, we wanted to also evaluate this configuration. Results from our resistivity modelling show that gradient electrode configuration yields the best result, with regards to mapping weakness zones in the subsurface (Reiser et al. 2009). Inversion options, available in the software, can further improve the modeling results. For example, to enhance the image for vertical structures a vertical/horizontal filter value 2 is preferred, while for horizontal layers the vertical/horizontal filter value 0.5 is preferable. Seaton and Burbey (2002) compared the results from field measurements made using Wenner, WennerSchlumberger, dipole-dipole and pole-pole electrode configurations. They concluded that dipole-dipole has the highest resolution, and sensitivity to geologic detail and greater depth of investigation than Wenner and WennerSchlumberger, while pole-pole has the greatest depth of investigation. It should be noted that Seaton and Burbey (2002) did not consider gradient as an electrode configuration during their comparisons. The dipole-dipole may suffer from low signal to noise ratio, therefore we propose that gradient is a practical electrode configuration when mapping vertical structures.

\section{Modelling of resistivity contrast}

The resistivity method is dependent on a minimum contrast between unaltered bedrock and potential weakness zones. Results from our modelling show that if the resistivity contrast is in the order of $1 / 5$ or lower, between the fracture zone and the host rock, the response is unambiguous. For resistivity contrasts in the order of $2 / 5$, the response becomes less pronounced (Reiser et al. 2009). The practical consequence of this is that it may be difficult to map fracture zones in bedrock with initial low resistivities.

\section{Modelling of soil cover}

Changes in the resistivity and thickness of the soil cover have a noticeable impact on the result. A 10-m-thick overburden, with resistivity of $1,000 \Omega \mathrm{m}$ (dry sand), does not appear to significantly influence the response from a fractured zone beneath. With a soil cover of $500 \Omega \mathrm{m}$ (water saturated sand), it is still possible to observe the fracture zone, but artificial effects, such as low resistivity adjacent to the zone, can occur. A resistivity of $100 \Omega \mathrm{m}$ in the soil cover deforms the response dramatically; however, it is still possible to pinpoint a fractured zone. With a $10-\mathrm{m}-$ thick cover with resistivity of $10 \Omega \mathrm{m}$ (marine clay), no or very little response was detectable of the fracture zone in the host rock beneath the soil cover (Reiser et al. 2009), which illustrates the classic downfall of resistivity methods.

Modelling the width of fracture zones

The effect of changing the width of fracture zones is shown in Fig. 2. A 5-m-thick zone is possible to see, however, the resistivity towards the depth is much higher and the zone is wider than in the model. The width close to the surface agrees quite well with the modelled width for all zone thicknesses. The artificial effects of decreasing resistivity and increasing width towards the depth seem to be less pronounced when the zone width increases.

Modelling the vertical extent of fracture zones

The effect of changing the vertical extent of fracture zones is shown in Fig. 3. The resistivity data shows that it is possible to confidently estimate how deep a fracture zone reaches, and the near surface resistivity value is the same as in the model. However, some artificial effects are also apparent. For the deeper parts, the inverted data show a 


\section{Gradient}

Standard inversion, $\mathrm{V} / \mathrm{H}=2$

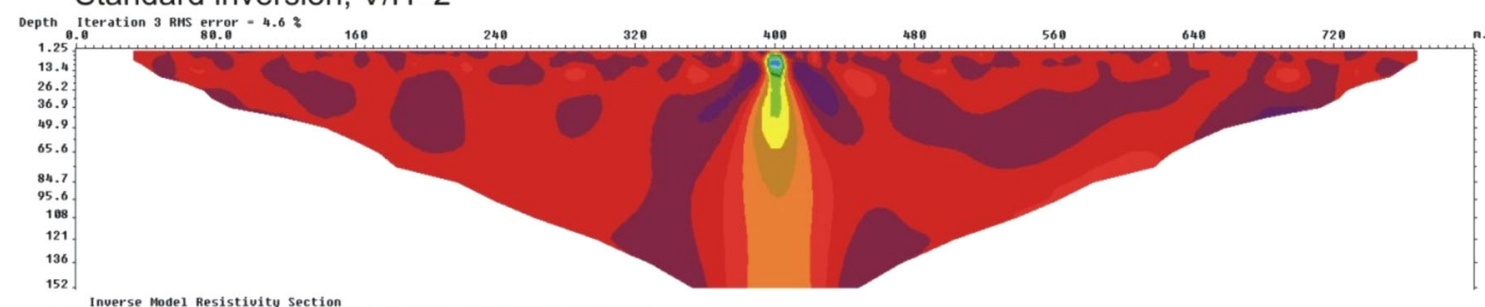

$\square_{200}^{\text {Inverse Mode1 Resistivity Section }}{ }_{318} \underbrace{}_{504} \square_{200} \square_{3202} \square_{5084}$

\section{Gradient}

Standard inversion, $\mathrm{V} / \mathrm{H}=2$

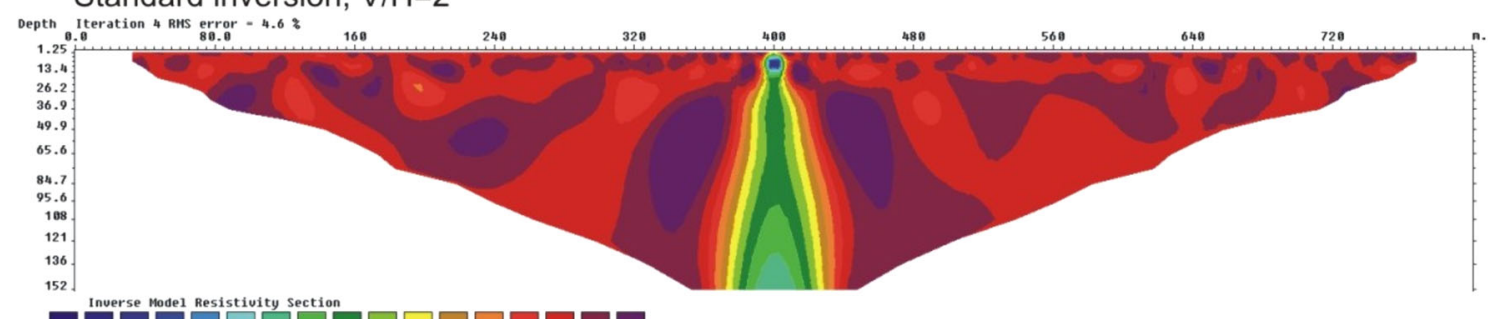

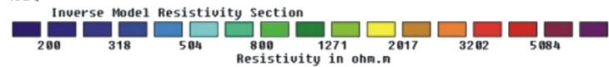

\section{Gradient}

Standard inversion, $\mathrm{V} / \mathrm{H}=2$

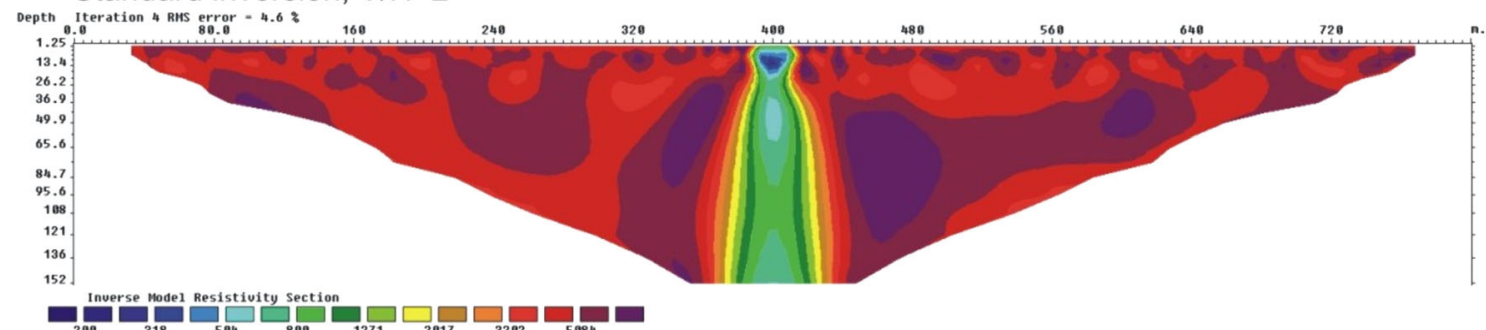

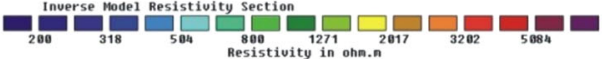

\section{Gradient}

Standard inversion, $\mathrm{V} / \mathrm{H}=2$

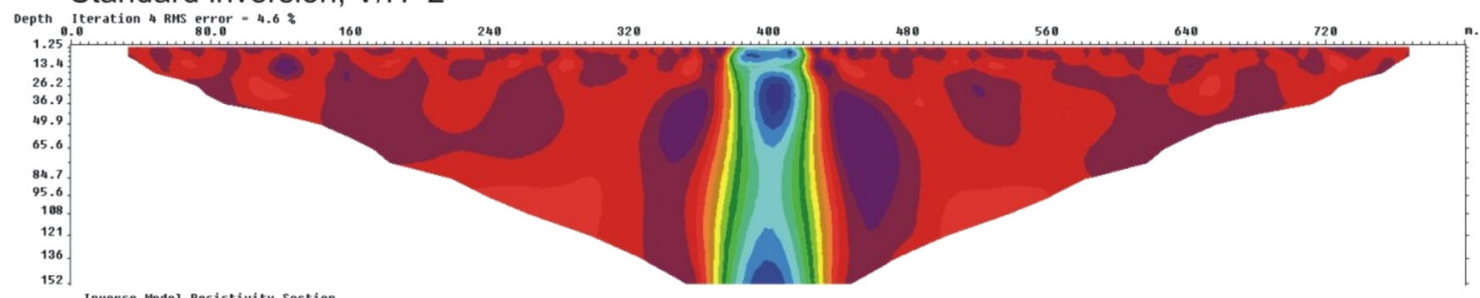

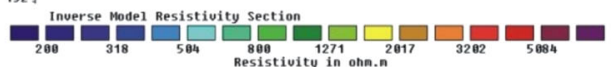

unit electrode spacing is $10.0 \mathrm{n}$.

\section{Synthetic model}

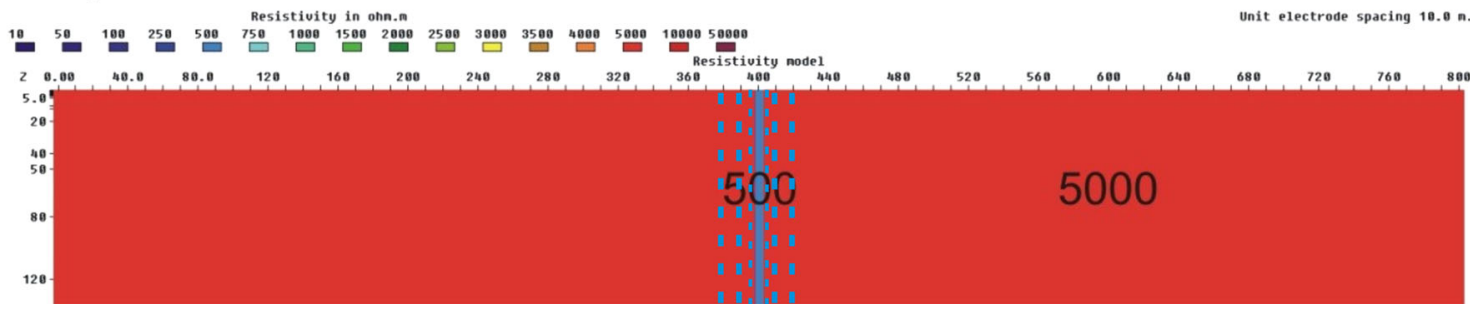

Fig. 2 Modelling of resistivity response with examples of changing the width of the zone. The width of the zone is $5 \mathrm{~m}$ at $t o p, 10,20$ and $40 \mathrm{~m}$ at bottom. The zone has a resistivity of $500 \Omega \mathrm{m}$ in a host rock of $5,000 \Omega \mathrm{m}$ 


\section{Gradient}

Standard inversion, $\mathrm{V} / \mathrm{H}=2$

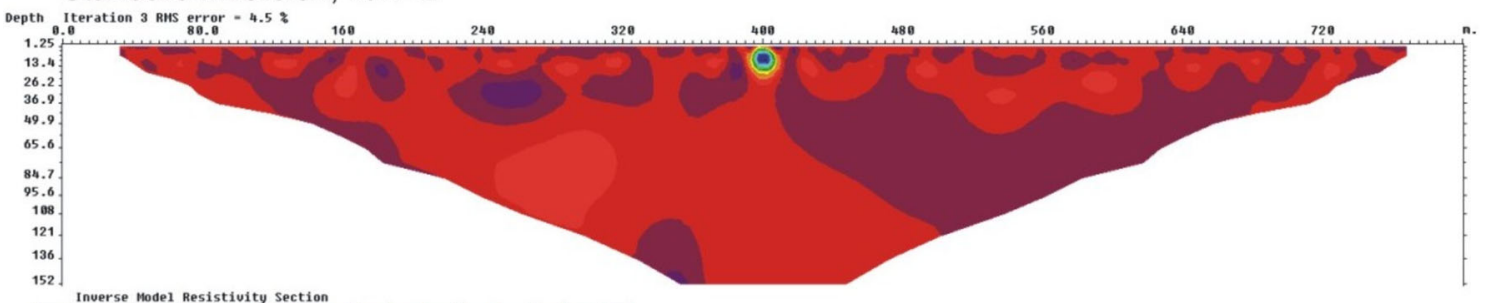

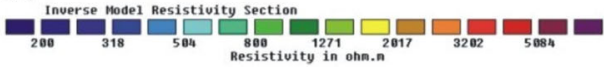

\section{Gradient}

Standard inversion, $\mathrm{V} / \mathrm{H}=2$

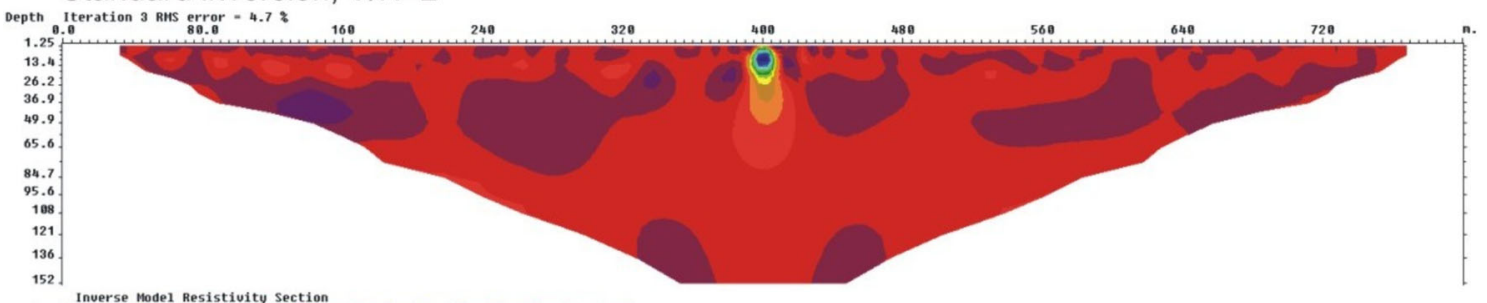

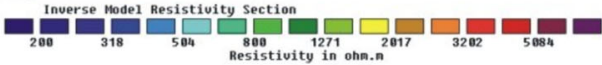

\section{Gradient}

Standard inversion, $\mathrm{V} / \mathrm{H}=2$

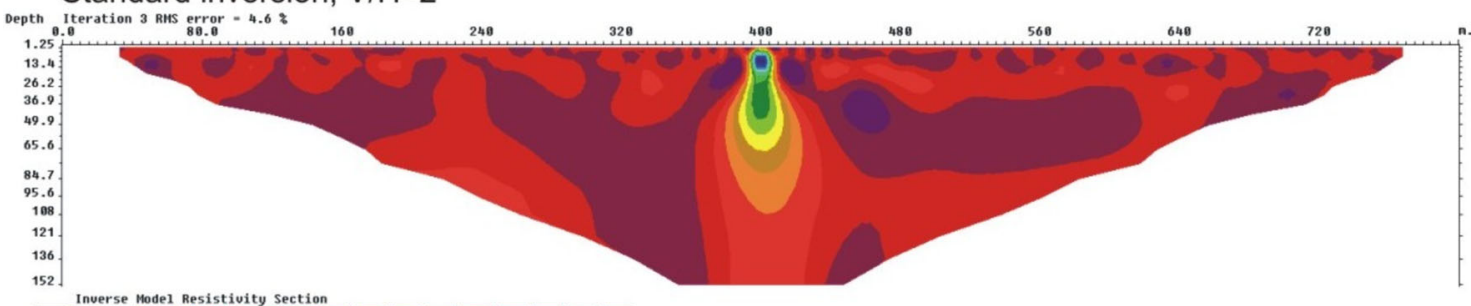

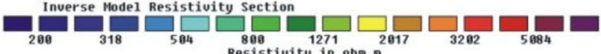

\section{Gradient}

Standard inversion, $\mathrm{V} / \mathrm{H}=2$

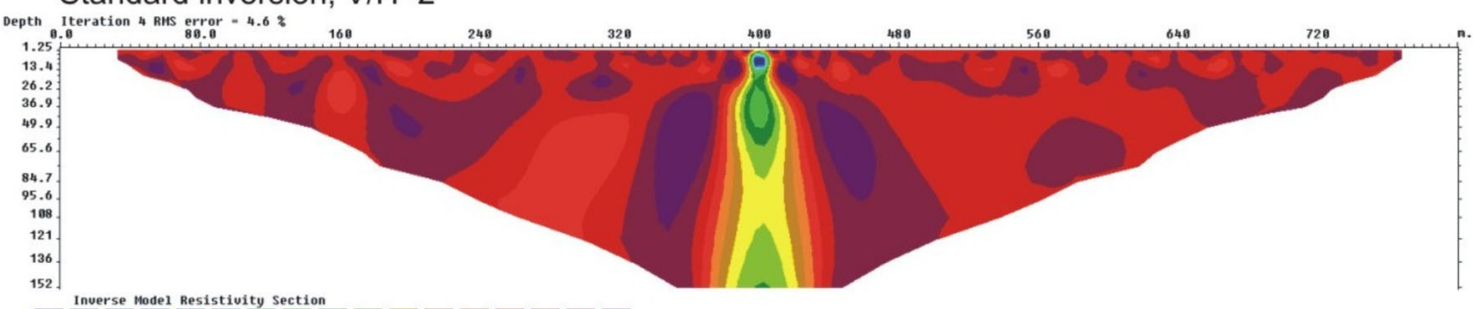

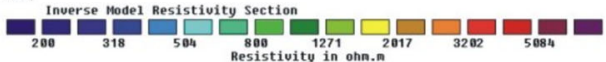

noit electrode spacing is $18.0 \mathrm{n}$

\section{Synthetic model}

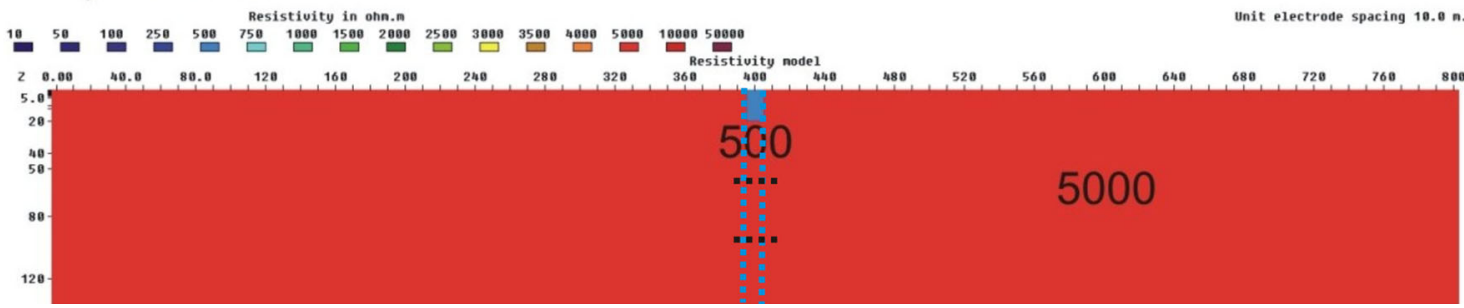

Fig. 3 Modelling of resistivity responses with examples of different depth extent of the zone. The depths of the zone is $20 \mathrm{~m}$ at top. 40,80 and $150 \mathrm{~m}$ at the bottom. The zone is $10 \mathrm{~m}$ thick and has a resistivity of $500 \Omega \mathrm{m}$ in a host rock of 5,000 $\Omega \mathrm{m}$ 


\section{Gradient}

Standard inversion, $\mathrm{V} / \mathrm{H}=2$

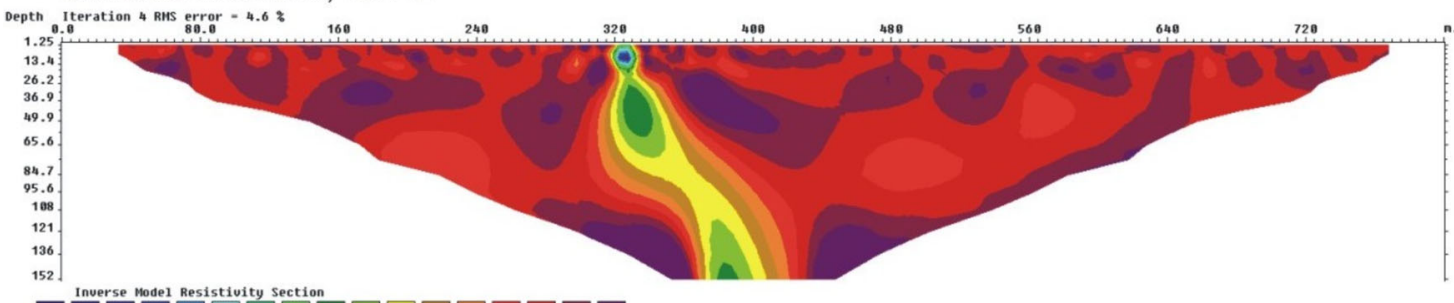

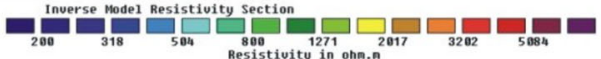

Gradient

Standard inversion, $\mathrm{V} / \mathrm{H}=2$

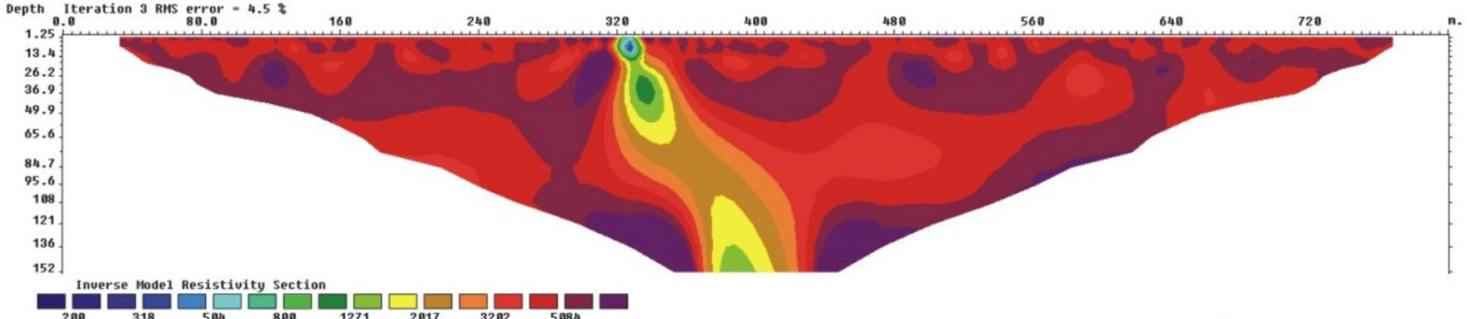

\section{Gradient}

Standard inversion, $\mathrm{V} / \mathrm{H}=1$

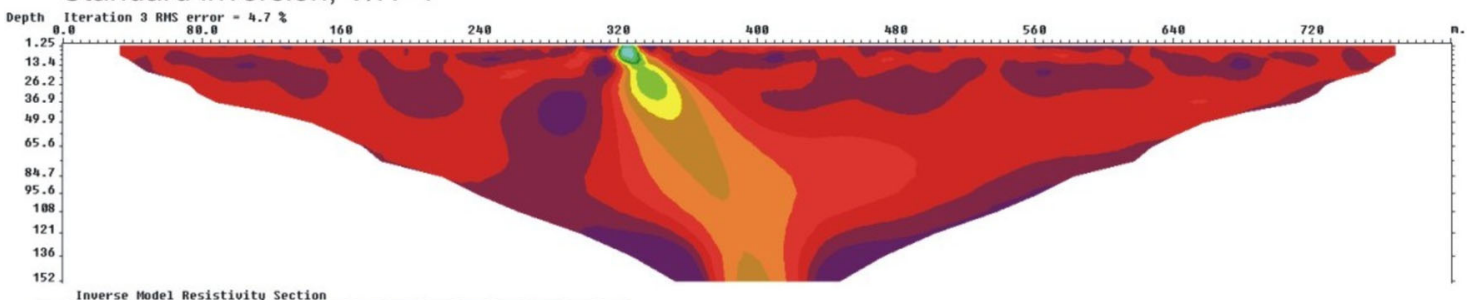

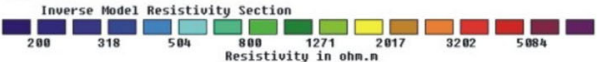

\section{Gradient}

Standard inversion, $\mathrm{V} / \mathrm{H}=1$

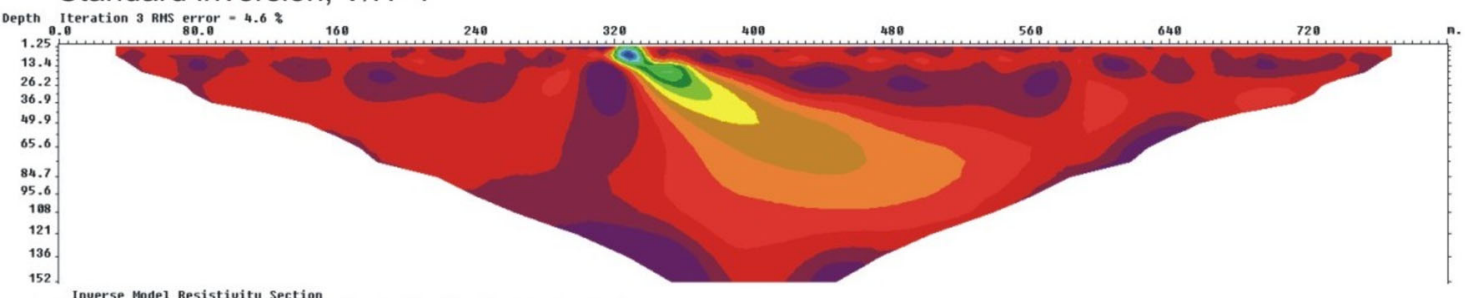

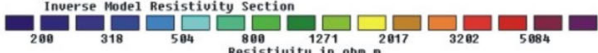

\section{Synthetic model}

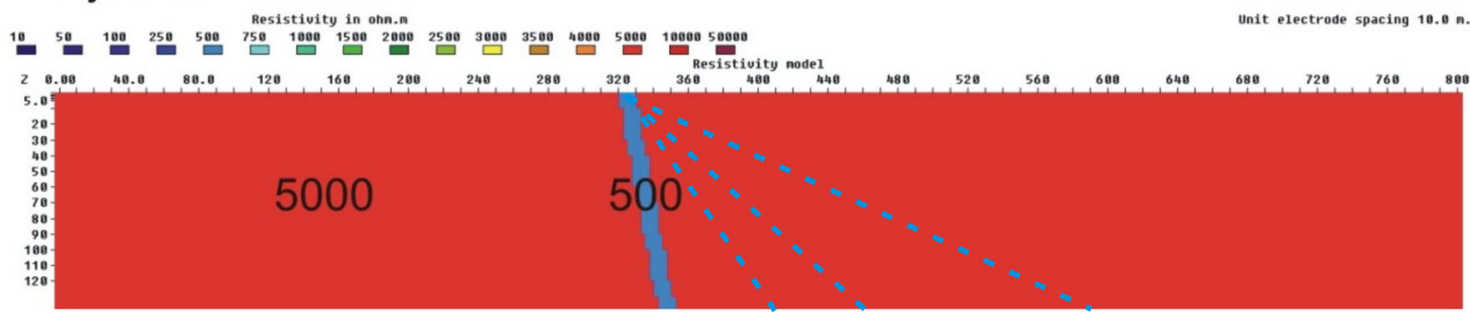

Fig. 4 Modelling of resistivity responses with examples of different dip of the zone, with $75^{\circ}$ at top, 60,45 and $30^{\circ}$ dip at bottom. The zone is $10 \mathrm{~m}$ thick and has a resistivity of $500 \Omega \mathrm{m}$ in a host rock of $5,000 \Omega \mathrm{m}$ 
downward decrease in resistivity, while the width of the fracture zone appears to be increasing by depth.

Modelling the dip of fracture zones

The effect of changing the dip of fracture zones is shown in Fig. 4, while the response from a corresponding vertical model is shown in Fig. 2. A fracture zone with a dip of $75^{\circ}$ will appear as close to vertical in the shallowest part, but with a clear deviation from vertical with the correct direction. Dips of $60^{\circ}, 45^{\circ}$ and $30^{\circ}$ show a clear response with the right direction, but show some artificial effects with deviation both in shape and resistivity level. These artificial effects complicate the interpretation in actual cases.

\section{Defining the interpretation model}

The Lunner road tunnel was one of the first tunnels in Norway, with the 2D resistivity method (ERT) initially performed in 2001 (Rønning 2003). The tunnel is located ca. $40 \mathrm{~km}$ north of Oslo (Fig. 1), and is part of the Rv 35 between Lunner and the Gardermoen Airport. The tunnel breakthrough was achieved in October 2002, it is $3.8 \mathrm{~km}$ long, has a $62-\mathrm{m}^{2}$ (T9)-profile, and the rock cover varies from 20 to $230 \mathrm{~m}$. Due to environmental reasons, sections of the tunnel had water inflow criteria as low as 4 to $201 / \mathrm{min}$ per $100-\mathrm{m}$ tunnel (Holmøy 2008). During the tunnel excavation, high levels of water leakage were encountered. The results from our work on this tunnel were so encouraging that the 2D resistivity method was followed up in the subsequent years, and applied to other tunnel construction projects in Norway.

\section{Geological setting}

The 3.8-km-long Lunner tunnel traverses through CambroSilurian meta-sedimentary rocks, and Permian intrusive and extrusive rocks of the Oslo igneous province (Nordgulen 1999; Fig. 5). The geology along the tunnel is divided into two groups; the Hadeland sedimentary sequence of Cambro-Silurian rock to the west, and the Nordmarka plutonic and volcanic rocks of Late Carboniferous and Permian age to the east (Fig. 5). The sedimentary sequence in the west is dominated by clay shale, limestone and marl, which is metamorphosed to hornfels around the contact to the east. The Nordmarka group is here composed of syenite, agglomerate, and rhyolite trachyte (Lutro and Nordgulen 2004). Several lineaments that are both lithological contacts and fault or fracture zones are mapped at the surface (Fig. 5, Elvebakk and Braathen 2001). The resistivity profile presented here runs through plutonic and volcanic rocks of the Nordmarka group (Fig. 5). The resistivity in the sedimentary rocks is normally $300-500 \Omega \mathrm{m}$, and between 500 and $6,000 \Omega \mathrm{m}$ for the volcanic rocks, while the resistivity in the unfractured igneous rocks is commonly above 6,000 $\Omega \mathrm{m}$ (Rønning and Dalsegg 2001; Dalsegg and Rønning 2002). The rock types have normally very low porosity, and free water will only occur in fractures. Due to the relatively high resistivities, this area is ideal for geoelectric measurements, although the rough topography and the presence of the lake hamper the positioning of the geophysical profiles over the tunnel.

Prior to our investigations, a number of structures such as faults and fractures, which could potentially cause excavation problems, were mapped (Kirkeby and Iversen 1996; Elvebakk and Braathen 2001).

Field measurements

2D resistivity was measured for a length of 2,500 $\mathrm{m}$ (total) along the Lunner tunnel (Rønning and Dalsegg 2001). In this study, we looked at the easternmost $1,000 \mathrm{~m}$ of this profile (Dalsegg and Rønning 2002). Based on the resistivity results, two boreholes were drilled, both of them dipping towards and intersecting zones with resistivity lows at the tunnel level around $50 \mathrm{~m}$ below the surface. The wells were logged with an optical televiewer (OPTV), resistivity probe and a sonic probe $(P$ - and $S$-wave velocities), and test pumped in combination with water flow measurements (Elvebakk and Braathen 2001; Elvebakk 2012). Also based on the results from the resistivity profiling, two short lines of refraction seismic were measured (Pedersen 2003).

\section{Results from the Lunner tunnel}

Results of the geophysical mapping are shown in Fig. 6 . The resistivity profile located all four zones previously mapped on the surface (P, Q, R and S, see Fig. 6), and in addition indicated the dip and depth extent of the zones. Zone $P$ is mapped as a narrow zone, $<5 \mathrm{~m}$ thick, with resistivity values down to ca. 1,500 $\Omega \mathrm{m}$. Zone $\mathrm{Q}$ has an approximate width of $8-10 \mathrm{~m}$, indicating a dip to the east of ca. $75^{\circ}$, and has resistivity values down to ca. $1,500 \Omega \mathrm{m}$. Further to the east is zone $\mathrm{R}$, which exhibits an approximate width of $40 \mathrm{~m}$ and indicates a steep zone that has resistivity values below $500 \Omega \mathrm{m}$ in the central part (Fig. 6). Zone $S$ is a steep, narrow zone $<5 \mathrm{~m}$ wide and showing resistivity values $<1,000$, but higher than $660 \Omega \mathrm{m}$. Two seismic profiles cover zones P, Q and R (see top of Fig. 6). Zone $P$ is indicated as a 15 -m-wide zone with a near-surface velocity of $3,800 \mathrm{~m} / \mathrm{s}$ that seems to disappear towards the depth according to Pedersen (2003). Zone $\mathrm{Q}$ does not give any response at all in the refraction 
Fig. 5 Geophysical

investigations and geological surface mapping as part of the feasibility studies for the Lunner tunnel, Rv 35 (see Fig. 1 for location). Aerial photo showing the tunnel trace (yellow dashed line), resistivity profile (black dashed line) and fault/fracture zones mapped on the surface (red dashed lines), with the locations of two boreholes. Bottom Geological map of the area (Lutro and Nordgulen 2004)

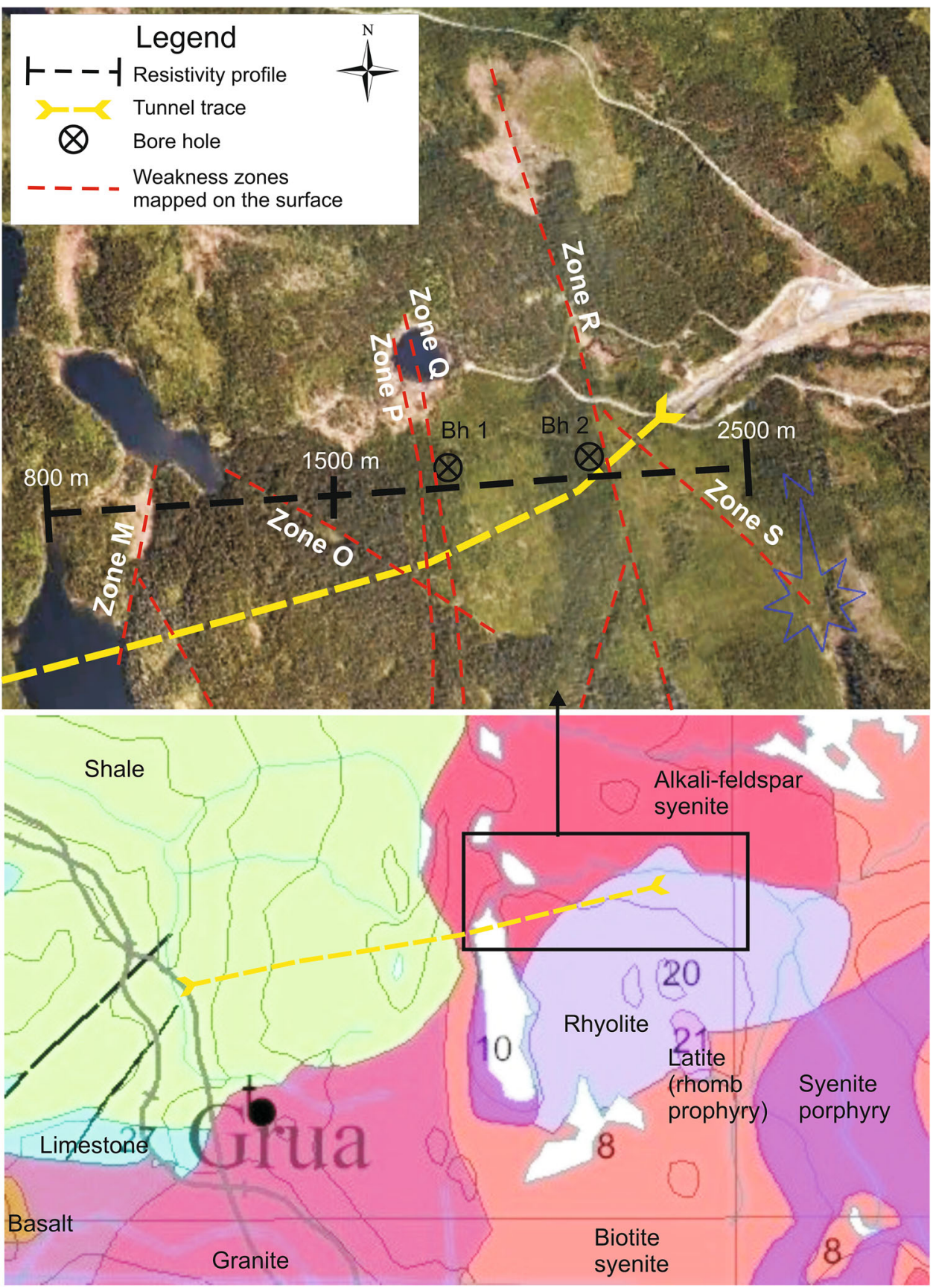

seismic data (top profile in Fig. 6). The seismic line covering zone $\mathrm{R}$ shows a fracture zone that is ca. 40-m-wide and has a seismic velocity varying from 3,300 to $3,700 \mathrm{~m} / \mathrm{s}$ at the depth. This is in good agreement with the resistivity data from the same area (Fig. 6).

The two most pronounced zones $(\mathrm{Q}$ and $\mathrm{R})$ were drilled as indicated in Fig. 6. Borehole 6 in zone Q is $120 \mathrm{~m}$ deep, dipping $65^{\circ}$ towards the west, while borehole 7 in zone $\mathrm{R}$ was drilled to a depth of $80 \mathrm{~m}$ dipping $65^{\circ}$ towards the east. The water yield was higher than $7,100 \mathrm{l} / \mathrm{h}$ (capacity of the pump) in borehole 6 , and 1,000 $\mathrm{l} / \mathrm{h}$ in borehole 7 , which resulted in the collapse of the borehole, indicating a large clay zone that had resistivity values below $500 \Omega \mathrm{m}$. Inspection of borehole 6 with an optical televiewer (OPTV) proved fresh rock with individual open fractures, while borehole 7 was intensively fractured and contained altered rock (Elvebakk 2012). During tunnel construction, zone R, with resistivity values below $500 \Omega \mathrm{m}$ (Fig. 6), had poor rock quality. Despite a reduced blast length, extensive support and grouting mass (from 1,000 to $>2,000 \mathrm{~kg} / \mathrm{m}$ ), rock fall from the tunnel sealing occurred and the tunnel progress was $<10 \mathrm{~m}$ a week. The permanent rock support was $40 \mathrm{~m}$ of shotcrete, and $4-8$ bolts (sometimes more) per metre of tunnel (pers. com.). 

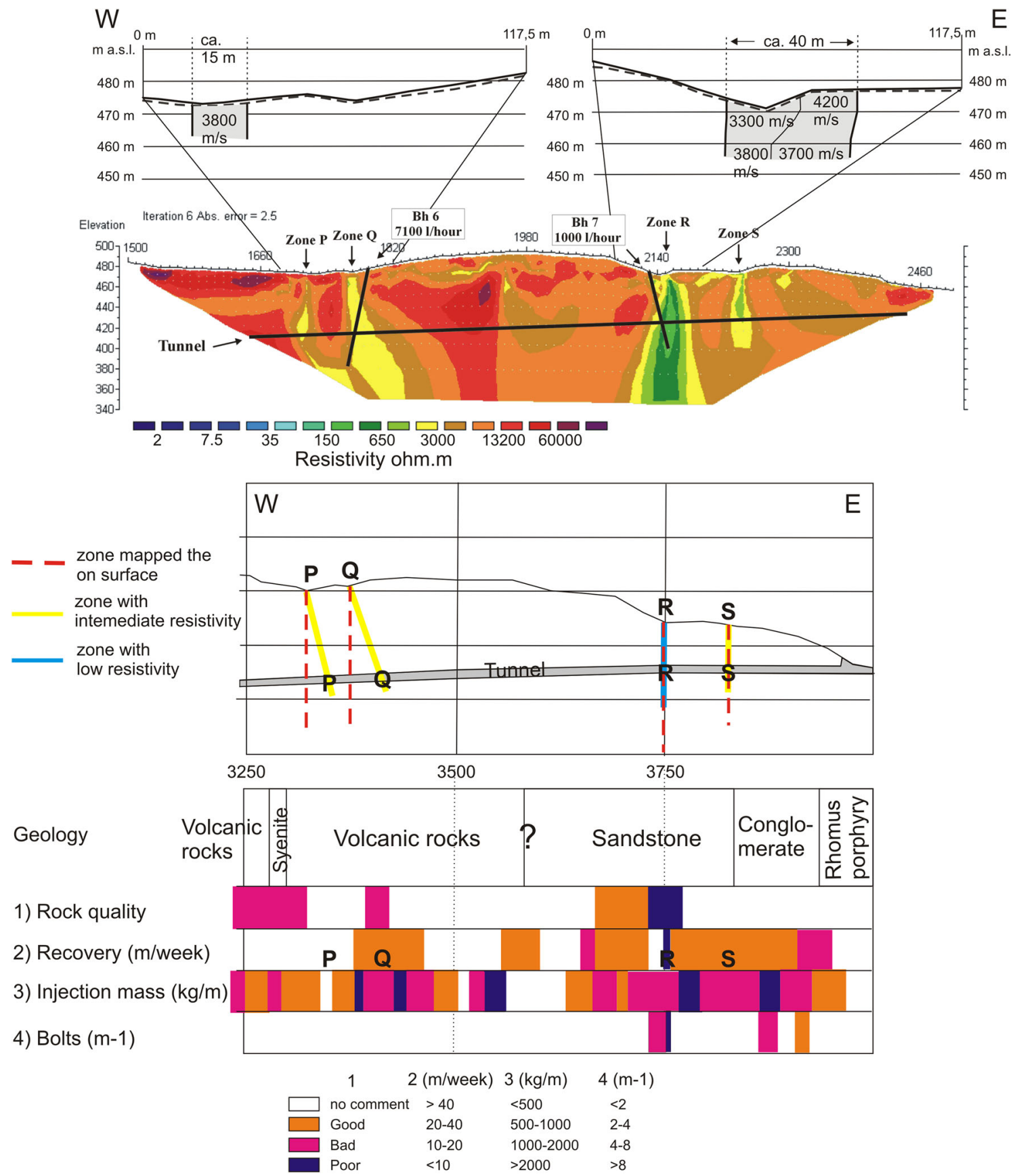

Fig. 6 Geophysical data from profiles along the eastern part of the Lunner tunnel trace, with comparative tunnel data (see Fig. 5 for location of the profile). Top two refraction seismic profiles covering the essential zones, P, Q and R (Pedersen 2003). Zone P and R are identified by seismic, but not zone $\mathrm{Q}$. Middle resistivity profile with

Characterisation of zones based on resistivity values

Results from the Lunner tunnel is a classic example of resistivity values, characterisation of weakness zones, and bedrock quality. In addition to the problems described above, two other boreholes drilled into rock mass with resistivity values $<500 \Omega$ m collapsed, and two other rock
Wenner electrode configuration. The resistivity profile indicates all fault and/or fracture zones that are mapped on the surface, showing the width, dip and extent of the zones. Bottom: Results from tunnel mapping and production (Rønning 2003)

mass zones with a surface mapped resistivity between 500 and 3,000 $\Omega \mathrm{m}$ caused high water leakage in the tunnel. This study formed the basis of the proposed model for characterisation of zones and rock mass, divided into three classes based on resistivity values. High resistivity of $>3,000 \Omega \mathrm{m}$ indicate good rock quality. Intermediate values in the range of $3,000-500 \Omega \mathrm{m}$ indicate fractured 
Table 1 Characterisation of weakness zones and rock quality based on resistivity values, unit in $\Omega \mathrm{m}$ standard colour scale used by the NGU

\begin{tabular}{|l|c|l|}
\hline $\begin{array}{l}\text { Resistivity values } \\
\text { (NGU colour scale) }\end{array}$ & Resistivity values & Characterisation \\
\hline & $>3000 \Omega \mathrm{m}$ & Good rock quality \\
\cline { 2 - 3 } & $3000-500 \Omega \mathrm{m}$ & $\begin{array}{l}\text { Fractured rock and } \\
\text { water leakage }\end{array}$ \\
\hline$<500 \Omega \mathrm{m}$ & $\begin{array}{l}\text { Instable rock mass } \\
\text { with clay and } \\
\text { water leakage }\end{array}$ \\
\hline
\end{tabular}

bedrock and potential water leakage. Low resistivity values of $<500 \Omega \mathrm{m}$ indicate unstable rock with fractures and zones of clay and water. These delineations are summarised in Table 1.

\section{Critical testing of the interpretation model}

Three case studies from Norwegian tunnels have been selected to show the use of geophysical mapping as an aid for tunnel planning, particularly the resistivity method, which has advantages in mapping details compared to more traditional methods, such as refraction seismic and VLFEM. Further, we compare how the results from the tunnel correlate with the geophysical and surface mapping, as well as how the results coincide with the proposed characterisation model. The case studies are; the Hanekleiv tunnel at E 18 in Vestfold County, the Vadfoss tunnel at Rv 38 in Krager $\varnothing$, Telemark County, and the Ravneheia tunnel at Rv 465 in Vest-Agder County (see Fig. 1 for location). In the first tunnel, rock fall occurred ca. 8 years after the tunnel was finished, while the two latter tunnels encountered problems of instability during excavation.

\section{The Hanekleiv tunnel at E 18 in Vestfold County}

The Hanekleiv tunnel was constructed in 1996-1998, and is part of the E 18 between Sande and Holmestrand in Vestfold County. Hanekleiv has two parallel tunnels, each $1,765 \mathrm{~m}$ long, with a $65-\mathrm{m}^{2}$ (T9) profile and $15-\mathrm{m}$ distance between the two tunnel lanes. On December 25th, 2006, a large rock fall of about $250 \mathrm{~m}^{3}$ occurred in the ceiling in the western tunnel lane. Fortunately, the incident occurred at a time of very little traffic flow, and there were no reported injuries. The bedrock of the area is syenite, an igneous rock that has intruded into the older sandstone of the Asker group, which is located to the north (Lutro and Nordgulen 2004; Nilsen et al. 2007; Fig. 7). The rock fall occurred along a zone of $25 \mathrm{~m}$ in length and ca. $2.5-\mathrm{m}-$ wide, configured by two parallel faults with $\mathrm{N} 030-\mathrm{N} 040^{\circ}$ strike and steep dip. Just north of the rock fall the fault consisted of $20-50 \mathrm{~cm}$ of non-cohesive fault rocks, which become 2.5-m-wide to the south. Where the rock fall occurred, fault rocks, including $2-5 \mathrm{~cm}$ of clay consisting of smectite, were observed on the fault plane (Nilsen et al. 2007). As a response to the rock fall, the NGU initiated a thorough investigation of the area, including geophysical mapping across the unstable zone with three different methods; VLF, seismic refraction, and 2D resistivity (ERT). Previous mapping with the AMAGER method showed several zones with potential deep weathering resulting in clay filling (Olesen 2006; Olesen et al. 2007). As indicated in Fig. 7 (bottom right), a zone of probable deep weathering is running north-south along the tunnel where it collapsed.

The geophysical profiles were collected across the tunnel directly above the tunnel collapse, and in an area with little soil coverage. The weakness zone is marked with an arrow in the profiles at coordinates ca. 245 , and the width of the zone is ca. $10 \mathrm{~m}$ (Fig. 8). The profile of seismic refraction is limited to $110 \mathrm{~m}$ across central parts of the unstable zone (top profile in Fig. 8). A thin, incoherent layer of overburden is shown with a seismic velocity of $300 \mathrm{~m} / \mathrm{s}$, which can be associated with bog. The bedrock velocity is generally low, $4,000 \mathrm{~m} / \mathrm{s}$, and a 9 -m-wide zone with velocity $2,900 \mathrm{~m} / \mathrm{s}$ is indicated at ca. coordinate 250 . The dip or depth extent of the zone is not indicated by seismic refraction (Fig. 8, Rønning et al. 2009b). The VLFEM profile gives a clear indication of the unstable zone with a significant dip anomaly of $10^{\circ}$ peak-peak (Paterson and Ronka 1971; middle profile in Fig. 8). The 2D resistivity profile is measured using gradient electrode configuration, with a 5-m electrode spacing (Rønning et al. $2009 \mathrm{~b}$ ). In general, the resistivity of the bedrock is higher than 3,000 $\Omega \mathrm{m}$, which indicates good rock quality (bottom profile in Fig. 8). The zone has steep dip towards the east, facing the western tunnel lane, and is interpreted as the unstable zone causing the rock fall in the tunnel. In the 


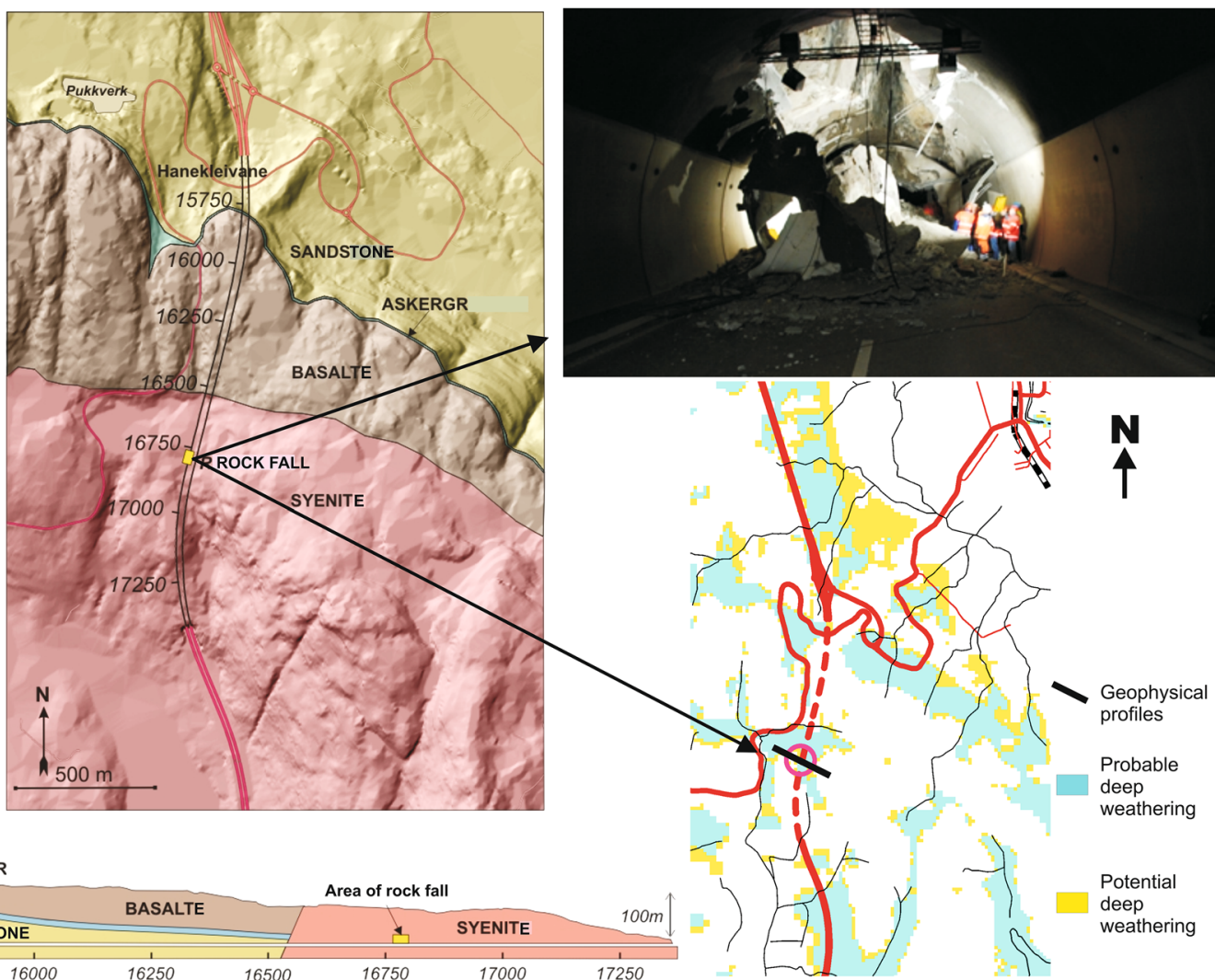

Fig. 7 Left a geological map showing the bedrock of the area and appurtenant cross-section, the road and the tunnel trace of Hanekleiv tunnel, and the area where the rock fall occurred (yellow square in map, Nilsen et al. 2007). Top right a picture of the rock fall along the

25-m-long zone confined by two parallel faults with $\mathrm{N} 030$ and $\mathrm{N}$ $040^{\circ}$ orientation, a short time after its occurrence. Bottom right AMAGER map of zones prone to deep weathering, which are more likely to cause instability due to clay filling (Olesen 2006)

profile, the zone seems to widen at depth, which most likely is an artificial effect (see modelling results). The very low resistivity at the deepest part of the profile is probably an effect of two zones intersecting at depth (Fig. 8). The resistivity value of the zone is $<400 \Omega \mathrm{m}$ close to the surface. According to our proposed model, this indicates poor rock quality and may give unstable rock mass and a clay-rich zone (Rønning et al. 2009b), which is in agreement with observations in the tunnel (Nilsen et al. 2007).

The Vadfoss tunnel at Rv 38 in Kragerø, Telemark County

The Vadfoss tunnel is $667 \mathrm{~m}$ long and located on $\mathrm{Rv} 38$, between Sannidal and Vadfoss in Kragerø municipality, Telemark County (Fig. 9). The tunnel was constructed during the period August 2007-January 2008, with a 65- $\mathrm{m}^{2}$ (T9) profile. The bedrock of the area consists of amphibolic and granitic gneisses of the Precambrian age (Padget and Brekke 1996). Several faults and fracture zones, with high fracture frequency and occurrence of clay minerals in the fault core, are observed. Tunnel excavation crossed several zones that needed extensive rock support, and in some of the zones active swelling clay was encountered (Langelid 2008).

A 2D resistivity profile was measured using gradient electrode configuration, with a 5-m electrode spacing (Rønning et al. 2009b). In general, the resistivity of the bedrock is ca. 3,000 $\Omega \mathrm{m}$ and higher (Fig. 9). Along the resistivity profile, five zones with low resistivity are identified, three of which were formerly mapped at the surface by geologists (Fig. 9). The resistivity value of the indentified zones is very low, locally below $200 \Omega \mathrm{m}$, and indicates unstable rock mass with clay content according to our proposed model. Four of the zones mapped in the resistivity profile show dip towards the west that coincides well with the zones mapped in the tunnel and at the surface (Fig. 9, Rønning et al. 2009b; Langelid 2008). These four zones have resistivity values below $500 \Omega \mathrm{m}$, and three of them caused instability in the tunnel that required extensive support due to clay content. One zone in the resistivity profile shows dip to the east. It is not mapped on the surface, and may correlate to a smaller vertical zone mapped 


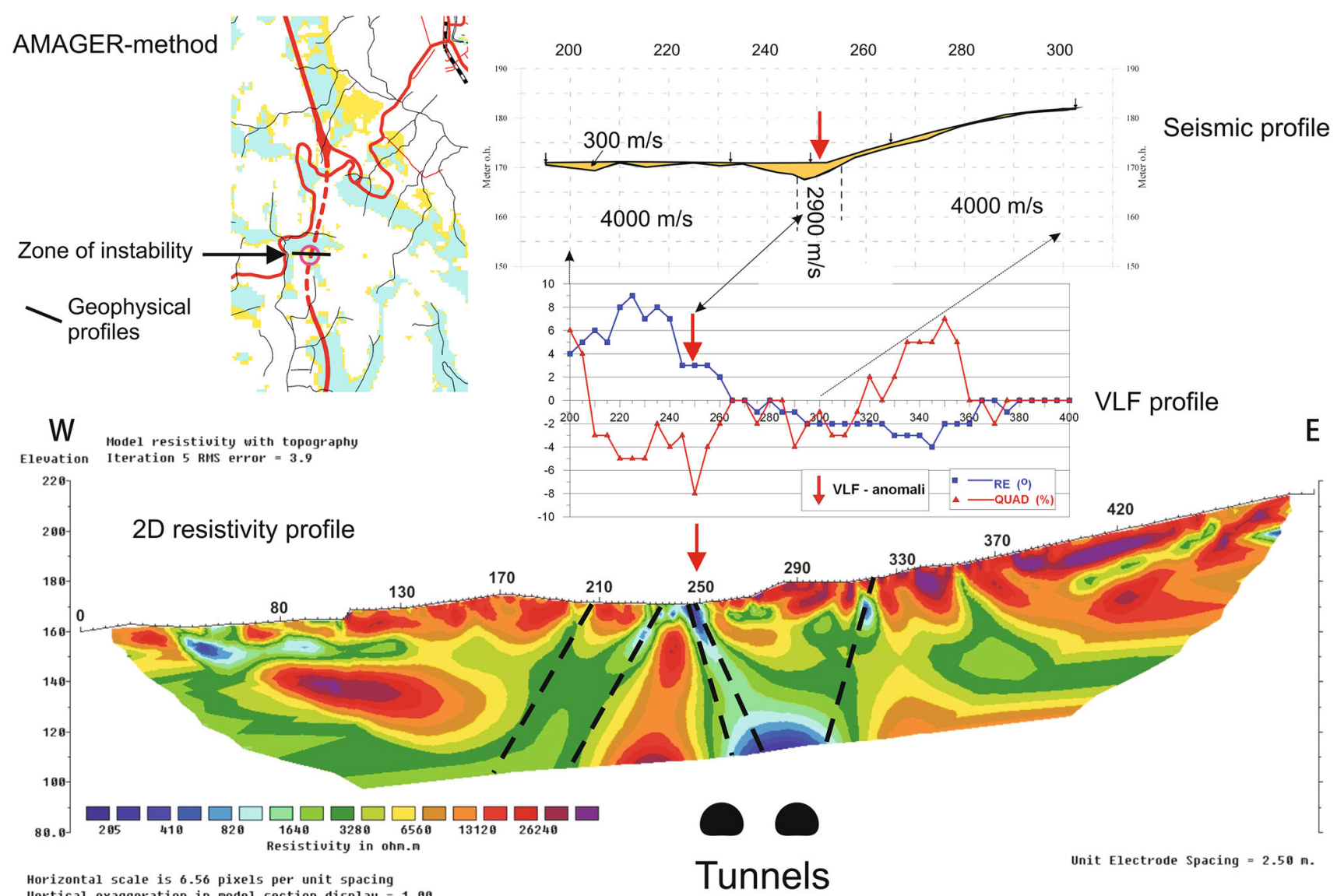

Vertical exaggeration in nodel section display $=1.00$

First electrode is located at $\mathbf{0 . 0} \mathrm{m}$.

Fig. 8 Geophysical profiles measured across the zone of instability in the Hanekleiv tunnel, E18, Vestfold County. The map with the AMAGER method shows a zone prone to deep weathering running parallel to the tunnel trace (Olesen 2006). Top profile the seismic refraction profile indicates a $10-\mathrm{m}$-wide zone (red arrow) and a few metres of overburden with a seismic velocity of $300 \mathrm{~m} / \mathrm{s}$. Middle profile the VLF-EM profile indicates a zone at the same location as the seismic profile. Bottom profile the 2D resistivity profile with a low resistivity zone of ca. 10-m width. The zone has a steep dip to the east and extends down to tunnel level. The tunnels are indicated in the bottom profile with an approximate location in the tunnel. This zone coincides with the part of the tunnel that is heavily supported (Langelid 2008; Fig. 9). Very low resistivity in the lower part of the section is probably caused by lack of resolution where several zones intersect.

The Ravneheia tunnel at Rv. 465 in Vest-Agder County

The Ravneheia tunnel is a 3.3-km-long tunnel, and is part of the Rv 465 between Hanesund and Sande, at Lista in Farsund municipality, Vest-Agder County (Fig. 10). On the 20 March 2007, a large rock fall occurred at the tunnel face during excavation, ca. $900 \mathrm{~m}$ from the northern tunnel mouth (Moen 2007). The unstable zone was a steep, 3-mwide fault with a NW-SE orientation containing intensely fractured fault rock and a clay-rich gouge, which intersected the tunnel at a high angle. The clay-rich gouge was analysed and smectite was identified, giving active swelling clay with a free swelling of $141 \%$ and a swelling pressure of $0.4 \mathrm{MPa}$ (Moen 2007). The mass of the rock fall was estimated at $3,000 \mathrm{~m}^{3}$, and there was the possibility for the rock fall to progress to the surface, ca. $170 \mathrm{~m}$ above the tunnel ceiling (Moen 2007). The tunnel intersects the bedrock charnockite, granite with pyroxene and feldspar (Falkum 1982; Moen 2007), and several weak zones were identified in the terrain as crevasses and valleys (Moen 2007; Fig. 10).

When studying in detail the map of zones prone to deep weathering, based on the AMAGER method by Olesen et al. (2012), the unstable zone encountered at the Ravneheia tunnel is indicated. This suggests that the zone of instability is prone to deep weathering. The $2 \mathrm{D}$ resistivity profile is measured with gradient electrode configuration, with a 5 and a $10 \mathrm{~m}$ electrode interval (Rønning et al. 


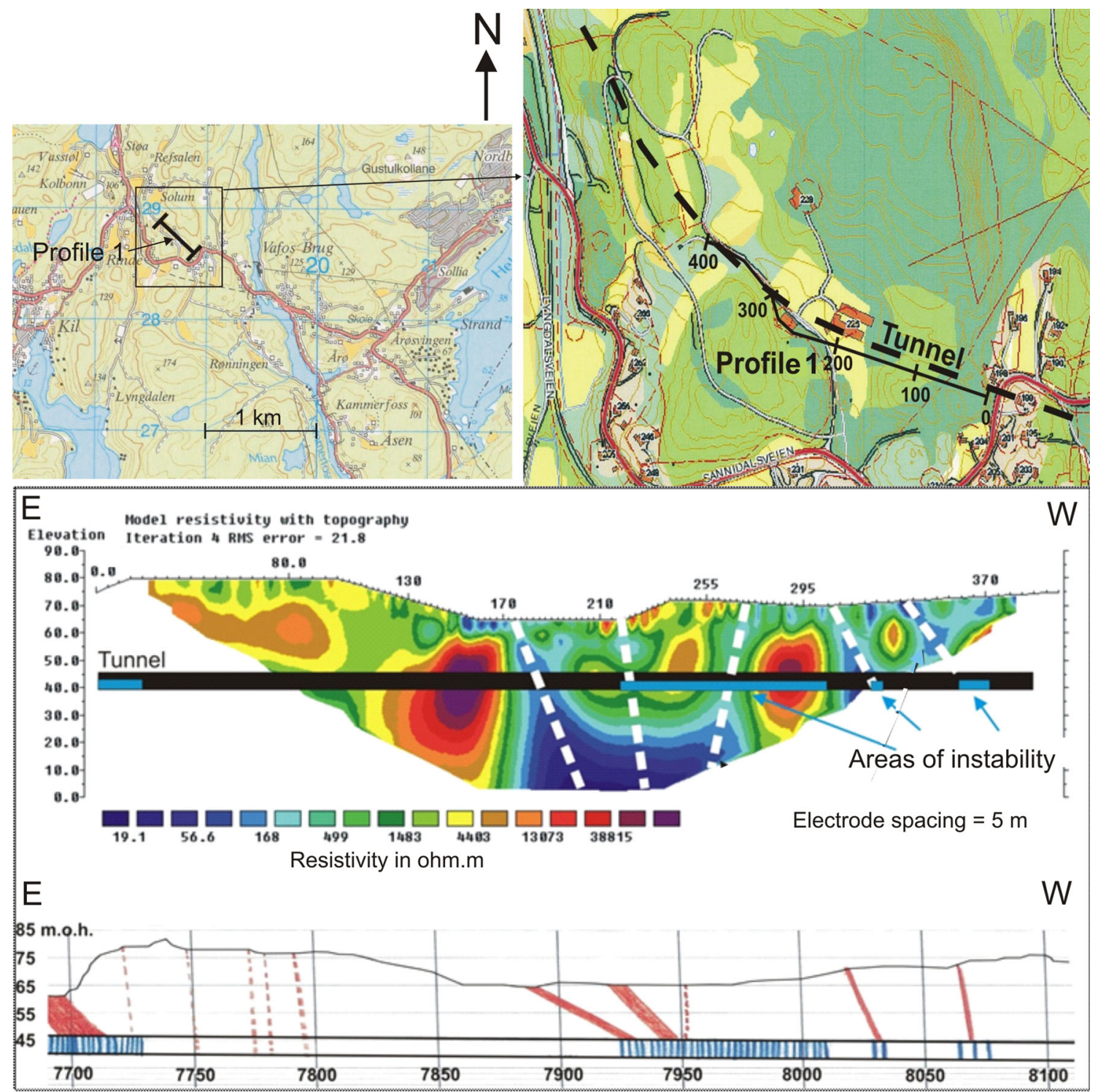

Larger faults/fracture zones mapped in tunnel - . - Smaller faults/fracture zones mapped in tunnel

\|IIIIIIII Rock support

Fig. 9 The Vadfoss tunnel along Rv 38 in Kragerø municipality, Telemark County. Top maps giving the location of the tunnel and the 2D resistivity profile (solid line) along parts of the tunnel trace (dashed line). Middle the 2D resistivity profile indicate five zones with low resistivity (white dashed lines); note that the profile is shown

2009b, Fig. 10). For the Ravneheia tunnel, four zones were mapped by geologists at the surface and the resistivity profiles represent the same zones, although the location of the profiles are somewhat offset from the surface mapping (Fig. 10). This is especially relevant for zone B where the rock fall occurred, located at coordinate 415 in the profile and with a dip towards the tunnel (bottom in Fig. 10). The resistivity response is as low as ca. $200 \Omega \mathrm{m}$ for the mapped zones, which indicate clay-bearing unstable rock from E to W. The electrode configuration used for this profile is gradient (Rønning et al. 2009b). Bottom map of zones encountered during the tunnel excavation and mapped at the surface, where the measures of rock support are symbolised in the tunnel mapping with shadings (Langelid 2008)

according to our proposed model (Table 1). In the resistivity profile (Fig. 10) zone B is estimated to be ca. $20-\mathrm{m}$ wide near the surface, while the unstable zone encountered at tunnel depth was estimated to $3 \mathrm{~m}$ (Moen 2007). The resistivity profile shows a generally low resistivity level $(<3,000 \Omega \mathrm{m}$ ), for approximately $200 \mathrm{~m}$, and to a depth of approximately $100 \mathrm{~m}$ between coordinate ca. 300-470 in Fig. 10. This is probably an effect of the deep weathering indicated in the area (Olesen et al. 2012). 

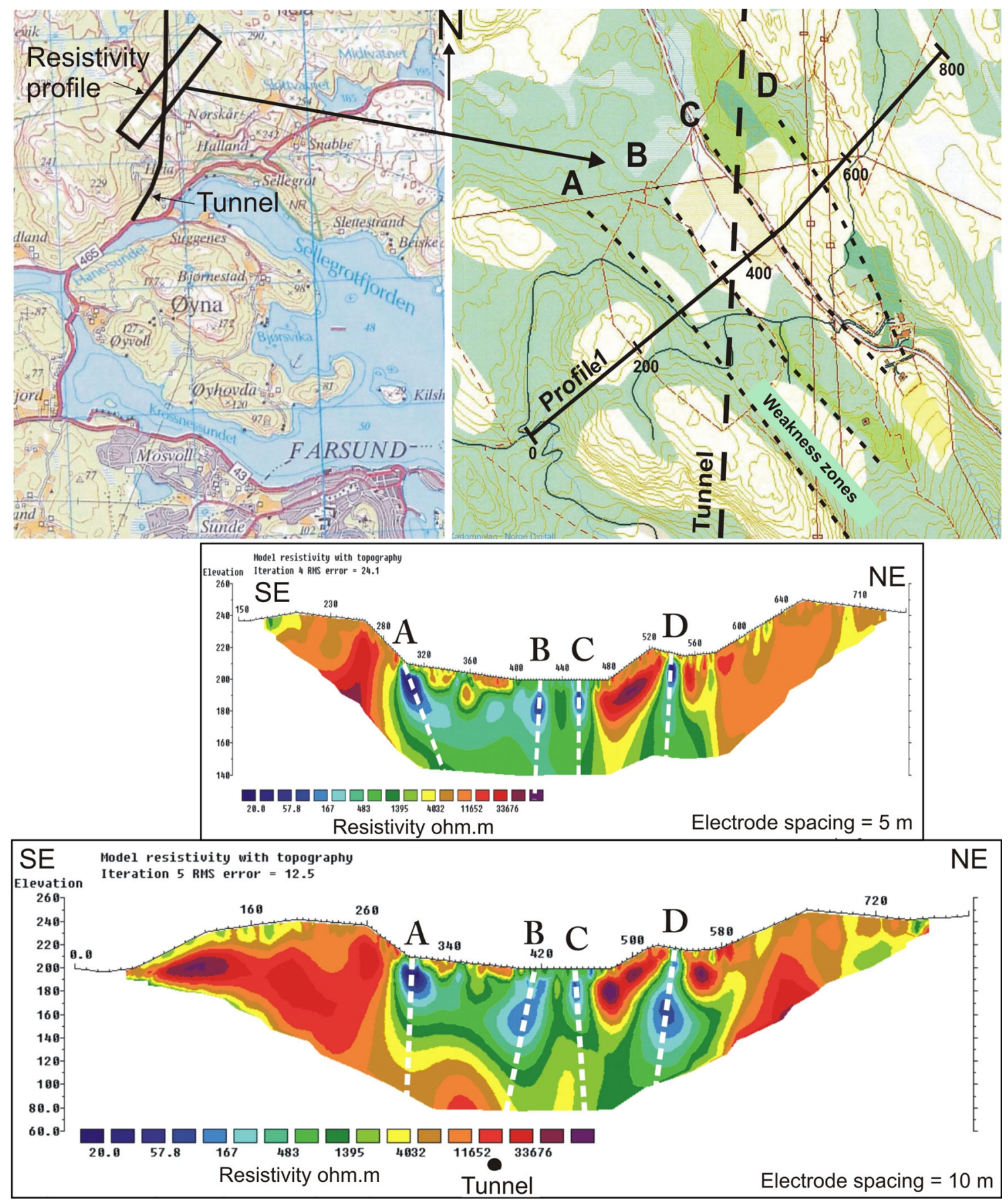

Fig. 10 The Ravneheia tunnel is located along the Rv 465, in VestAgder County. Top left a map showing the location of the tunnel with the town Farsund close by. Top right a detailed map showing the four weakness zones (black, dashed lines labelled $A-D$ ), which were mapped on the surface and the location of the $2 \mathrm{D}$ resistivity profile

\section{Discussion}

Comparison of geophysical methods

The AMAGER method (Olesen et al. 2007), where the low magnetic response together with low terrain can indicate (solid, black line). Zone B was the zone that caused the rock fall in the tunnel. The tunnel trace is given in a black, dashed line. Bottom the result of the resistivity profile with two electrode spacing, 5 and $10 \mathrm{~m}$, indicating all four zones (white, dashed lines) with dip direction and depth extent (Rønning et al. 2009b)

deeply weathered fracture zones, and the VLF-EM method, are able to locate weak zones in bedrock. Neither method can give a clear picture of the continuation of the zones towards the depth (depth extend and dip), however, a response on the AMAGER method will not occur without a certain volume of altered bedrock. 
Seismic refraction modelling has previously shown that it is not possible to obtain information regarding the vertical extent of fracture zones using the standard technique (e.g., Westerdahl 2003). The same study indicated that a depression in the bedrock surface might be falsely interpreted as a fracture zone. In Norway, where several glaciations have removed nearly all weathering surfaces, it is not possible to interpret the dip of fracture zones in seismic refraction.

Resistivity modelling was undertaken to investigate whether or not the resistivity method may overcome these problems (Reiser et al. 2009). Modelling has proved that the advantages with the resistivity (ERT) method are that it is able to locate a fractured zone, and in addition, indicate width, dip direction and depth extend of the zone. This is an advantage compared to methods such as seismic refraction, which cannot give dip direction nor differentiate a trench from a weakness zone (Westerdahl 2003), or the AMAGER and VLF methods that can only locate the zone.

The resistivity profile along the eastern part of the Lunner tunnel showed responses to all four of the previously mapped fracture zones. Only one (zone R) gave a clear response to seismic refraction (Fig. 6). This shows that, at least in this geologic setting, the resistivity method is more sensitive than the seismic refraction method. However, this leads to an important question-is the method too sensitive? Two zones (P and S; Fig. 6) gave a weak resistivity response, and were barely recognised during tunnel excavation. This shows us that we may use the strength of the resistivity anomaly as a problem indicator for tunnel construction. Zone Q, not seen on the seismic refraction, shows up as a steeply eastward dipping structure, with resistivity in the order of $2,000 \Omega \mathrm{m}$ (Fig. 6). The dip of the zone was confirmed by observation during tunnel excavation (Rønning 2003), and the dip coincided with the calculated dip of fractures from optical televiewer analysis (Elvebakk 2012).

The disadvantages of the resistivity method are that the data recovery at depth is limited to ca. $120 \mathrm{~m}$, where reliable data recovery is only considered down to ca. $80 \mathrm{~m}$ depths, with a $10-\mathrm{m}$ electrode spacing. The resolution of the method will decrease with increasing depth. Therefore, anomalies occurring at a depth below $80 \mathrm{~m}$ should be considered with care. In addition, artificial effects from interpretation are exacerbated at increasing depths, such as widening of the zones at the bottom, and interpretation can be difficult where several zones intersect. As shown in the Hanekleiv and Vadfoss examples, neighbouring zones may merge together at depth (Figs. 8, 9 ), and larger zones may overrule the effect of smaller zones so that they seem to gradually fade out. As with all geophysical methods, the resistivity method requires a certain degree of contrast in resistivity in the bedrock, i.e., between different types of bedrock and contrast between bedrock and weakness zones. Therefore, it is an advantage to have a priori information on bedrock resistivity. We have also observed that thick overburden with a low resistivity, especially in marine clay, prohibits the electric current from penetrating into the bedrock. In such cases, no information from fracture zones can be obtained. Both these effects reduce the possibility to map fracture zones in the subsurface.

Geometric and mineralogical characterisation of weakness zones

Modelling has showed that interpretation of the dip of the fracture zone is possible with the resistivity method. However, there are commonly some offsets between the zones mapped with resistivity and zones mapped in the tunnel. This may be due to incorrect coordinate locations, deviation on the surface between profiling and tunnel trace, and/or deviation in dip of the zone in the resistivity profile and natural dip of the zone, so that the offset at tunnel depth increases. After comparing many cases, there seems to be an up to $15^{\circ}$ offset, that is, the zones in the resistivity profiles are showing steeper dip than natural dip. Previous studies have illustrated that structures running parallel to the profile are difficult to detect in a $2 \mathrm{D}$ resistivity profile, while those cross-cutting the profile in most cases are very distinctive (Ganerød et al. 2006, 2010; Ganerød and Dalsegg 2011). Therefore, in order to obtain good results from $2 \mathrm{D}$ resistivity data, it is important to plan the profiling according to structures of interest.

The modelling has shown that the $2 \mathrm{D}$ resistivity method is able to constrain the vertical extent of fracture zones. The method also correctly images the width and resistivity value of the fracture zone close to the surface, but at deeper levels the zones will appear to be wider and with higher resistivity. The dip of the fracture zone can be indicated, although artificial effects are common. So far, our study shows that the resistivity method seems to work better for characterisation of the fracture zone than seismic refraction. In the modelling, we have used simple geological models. In nature, the situation is considerably more complicated, and the results we have achieved so far, should be considered as guidelines for future studies. Experience will always be necessary when interpreting resistivity results.

This study has also shown that the resistivity (ERT) method can characterise rock quality and identify unstable rock masses, and based on the presented results we propose the following interpretation model for crystalline bedrock:

- Resistivity values $>3,000 \Omega \mathrm{m}$ indicate good rock quality with minor water problems. 
- Intermediate resistivity values between 500 and $3,000 \Omega \mathrm{m}$ indicate rock mass with open fractures and significant water problems.

- Resistivity values $<500 \Omega \mathrm{m}$ indicate unstable rock, with fractures potentially filled by clay, and fewer water problems.

In the four case studies presented here, where resistivity value was $<500 \Omega \mathrm{m}$ in the fracture zones, clay minerals partly with swelling smectite were identified. At two other tunnel projects in Norway, Romeriksporten Railway tunnel and Lieråsen Railway tunnel, the resistivity in weak zones were $<500 \Omega \mathrm{m}$, and clay alteration on fractures were reported (Rønning et al. 2007).

In recent years, other follow-up studies on tunnels have confirmed the geometric and mineralogical characterisation that we suggest in this work (e.g., Arntsen 2012; Rohde and Skaug 2012). Arntsen (2012) suggest the resistivity method is better at mapping weakness zones compared to the seismic refraction method and (engineer) geological field mapping. For two tunnels, Arntsen (2012) show that seismic refraction identified half or less of the zones encountered in the tunnel during excavation, while resistivity profiling identified $66-90 \%$ of all weakness zones encountered in the tunnel. Our proposed interpretational model is confirmed by the two tunnel projects studied by Arntsen (2012).

A critical question is: can we transfer an interpretation model from one geological setting to another? So far, our comparison studies show that as long as the problem to be addressed is within crystalline bedrock, the interpretational model can be applied. Similar characterisation of rock with respect to tunnelling has previously been proposed by Danielsen and Dahlin (2009; Hallandsås tunnel in Sweden), where they indicate that alternation in resistivity values coincides with a change in rock conditions. Their results correlate well with the results presented here, where high resistivity values indicate good rock quality, while intermediate values indicate rock with water-bearing fractures or alteration of the bedrock.

\section{Electrode configuration for 2D resistivity (ERT)}

In this study, the presented results are executed with Wenner and gradient electrode configuration, and the synthetic modelling is done with gradient. Over the years, the Geological Survey of Norway has tested different electrode configurations and our experience has taught us that the Wenner configuration is preferable if the target is (sub) horizontal layers, such as sediments. For (sub) vertical structures, dipole-dipole is the preferred configuration for a long period, but this method suffers from low signalto-noise ratio. Recent modelling shows that gradient configuration will enhance (sub) vertical structures effectively (Reiser et al. 2009). Therefore, for the time being, gradient is the preferred configuration for field measurements where mapping of (sub) vertical structures is the purpose.

Dahlin and Zhou (2004) tested 10 different electrode configurations on an hypothetical survey using computer simulations, where five different geological settings were modelled (each with similar settings for all configurations in the test). This study showed that gradient and midpointpotential-referred measurements are well-suited to multichannel surveying, and that gradient may produce images that are comparable to those obtained with dipole-dipole and pole-dipole. Therefore, the electrode configurations of gradient, pole-dipole, dipole-dipole and Schlumberger were "strongly recommended for 2D resistivity imaging, where the final choice will be determined by the expected geology, the purpose of the survey, and logistical considerations" (Dahlin and Zhou 2004).

\section{Conclusions and outlook}

Resistivity modelling shows that the method is able to locate fracture zones and indicate the width, dip, and depth extent of fault/fracture zones in crystalline bedrock. Resistivity profiling along the Lunner tunnel gave responses from four previously mapped fault/fracture zones, and we were able to geometrically characterise them. Based on the combined resistivity results, optical televiewer inspection of boreholes, pumping tests, and observations in two boreholes, an interpretation model for rock quality is proposed.

The four case studies presented here show that geophysical mapping is able to locate zones of weakness that cause stability and/or water leakage problems in tunnels. The resistivity method is capable of identifying the zone, indicating the width and dip direction of the zone, and can differentiate between a trench in bedrock (shallow depth), and a weakness zone (greater depth).

A resistivity model for the characterisation of rock quality of the subsurface and weakness zones in crystalline bedrock is proposed. Further, a classification based on resistivity values is suggested with three classes, where $>3,000 \Omega \mathrm{m}=$ good rock quality, 3,000-500 $\Omega \mathrm{m}=$ fractured rock and water leakage, and $<500 \Omega \mathrm{m}=$ presence of clay, which gives unstable rock. So far, this model has passed critical tests at seven different tunnel projects in Norway.

The three additional methods presented here, the AMAGER method, seismic refraction, and VLF-EM, are all capable of locating zones of weakness, and seismic refraction can indicate the width of the zone. However, 
these methods cannot indicate the dip direction nor the depth extent of fault/fracture zones. The case studies presented here show that there is good correlation between geophysical mapping and geological mapping of zones at tunnel depth and at the surface.

In the future, the interpretation model should be tested through investigations in other tunnel projects. An overview of resistivity levels in different rock types should be compiled in order to be able to assess if the resistivity contrast would be adequate for successful measurements.

Acknowledgments We thank "Statens vegvesen" (The Norwegian Public Road Administration) for good cooperation, for making tunnel construction data available, and for permission to publish the data. We especially thank Audun Langelid and Kjetil Moen for contributing data and knowledge. The project was sponsored by the Directorate of Public Roads and the Geological Survey of Norway (NGU). The comments and suggestions from two anonymous reviewers have improved the quality of the paper. Gratitude to Camilla M. Wilkinson at NGU for improving the language and understanding ofthis article, and to Gwenn Peron-Pinvidic at NGU for translating the abstract to French.

Open Access This article is distributed under the terms of the Creative Commons Attribution License which permits any use, distribution, and reproduction in any medium, provided the original author(s) and the source are credited.

\section{References}

Arntsen ML (2012) The Eikrem and Knappe road tunnels: evaluation of refraction seismic, resistivity measurements and laboratory investigations as a part of the engineering geological investigations. M.Sc. thesis, Norwegian University of Technology and Science (NTNU, in Norwegian)

Barton N (2007) Rock quality, seismic velocity, attenuation and anisotropy. Taylor and Francis Group, London (Figure 5.36)

Dahlin T (1993) On the automation of 2D resistivity surveying for engineering and environmental applications. Thesis, Department of Engineering Geology, Lund Institute of Technology, Lund University, Lund. ISBN 91-628-1032-4

Dahlin T, Zhou B (2004) A numerical comparison of 2D resistivity imaging with 10 electrode arrays. Geophys Prospect 52(5):379-398. doi:10.1111/j.1365-2478.2004.00423.x

Dalsegg E, Rønning JS (2002) Tunnels for the citizens, geophysical measurements at eastern part of the Lunner tunnel, Oppland county. NGU report.106: 1-15 (in Norwegian). http://www.ngu. no/upload/Publikasjoner/Rapporter/2002/2002_106.pdf

Danielsen BE, Dahlin T (2009) Comparison of geoelectrical imaging and tunnel documentation at the Hallandsås tunnel, Sweden. Eng Geol 107:118-129

Elvebakk H (2012) Geophysical logging of boreholes at Grualia, Lunner. NGU Report 2011.009: 1-33 (in Norwegian). http:// www.ngu.no/upload/Publikasjoner/Rapporter/2011/2011_009. pdf

Elvebakk E, Braathen A (2001) Tunnels for the citizens. Borehole logging and structural studies at Grualia, Lunner municipality. NGU report 2001.117: 1-92 (in Norwegian). http://www.ngu.no/ upload/Publikasjoner/Rapporter/2001/2001_117.pdf

Falkum T (1982) Bedrock map MANDAL 1:250.000. Geological survey of Norway
Ganerød GV, Dalsegg E (2011) Geophysical measurements at HolmHolmestrand railroad tunnel, Holmestrand, Vestfold. NGU report 2011.005 (in Norwegian) http://www.ngu.no/upload/Pub likasjoner/Rapporter/2011/2011_005.pdf

Ganerød GV, Rønning JS, Dalsegg E, Elvebakk H, Holmøy KH, Nilsen B, Braathen A (2006) Comparison of geophysical methods for subsurface mapping of faults and fracture zones in a section of the Viggja road tunnel, Norway. Bull Eng Geol Environ 65: 231-243. ISSN: 1435-9529

Ganerød GV, Dalsegg E, Rønning JS (2010) 2D Resistivity along the Holm-Holmestrand-Nykirke railroad tunnel, Vestfold. NGU report 2009.068 (in Norwegian). http://www.ngu.no/upload/ Publikasjoner/Rapporter/2009/2009_068.pdf

Holmøy KH (2008) Significance of geological parameters for predicting water leakage in hard rock tunnels. Ph.D. Thesis, Department Geology and Mineral Resources Engineering, NTNU

Karlsrud K, Erikstad L, Snilsberg P (2003) Tunnels for the citizensinvestigations of and restrictions on water leakage to maintain the environment. Public Road Administration Oslo, Publ No 103: 1-98, ISSN 0803-6950 (in Norwegian) http://www. vegvesen.no/_attachment/61904/binary/15126

Kirkeby T, Iversen E (1996) Road 35 Grualia-Slettmoen, tunnel through Tveitmark top. Geological investigations. Report from "Veglaboratoriet" (in Norwegian)

Langelid A (2008) Final geological report for the Rv 38 Vadfoss tunnel. "Statens Vegvesen Region Sør", Report no. 2007017487-091 (in Norwegian)

Lindstrøm M, Kveen A (2004) Tunnels for the citizens-final report. Public Road Administration Oslo, Report Publ No 105: 1-71, ISSN 0803-6950 (in Norwegian). http://www.vegvesen.no/_ attachment/61902/binary/15124

Loke MH (2002) RES2DMOD version 3.01 Rapid 2D resistivity forward modelling using the finite-difference and finite-element methods. http://www.geoelectrical.com/download.html: 1-30

Loke MH (2007) RES2DINV version 3.56. Geoelectrical imaging 2D and 3D. Instruction manual. http://www.geoelectrical.com

Loke MH, Barker RD (1996a) Rapid least-square inversion of apparent resistivity pseudo sections by a quasi-newton method. Geophys Prospect 44:131-152

Loke MH, Barker RD (1996b) Practical techniques for 3D resistivity surveys and data inversion. Geophys Prospect 44:499-524

Lutro O, Nordgulen $\varnothing$ (2004) Bedrock map, Oslo rift 1:250.000. Geological Survey of Norway

Moen K (2007) Rock fall in the Ravneheia tunnel, Farsund. Fjellspregnings-, Bergmekanikk- og Geoteknikkdagen 2007, 5.1-5.19 (in Norwegian)

Nilsen B, Bollingmo P, Nordgulen $\varnothing$ (2007) Rock fall in the Hanekleiv tunnel 25. Dec 2006. Report from investigation group to the Department of Transportation (in Norwegian). http://www. regjeringen.no/upload/SD/Vedlegg/Veg\%20og\%20vegtrafikk/ Manus070213.pdf

Nordgulen Ø (1999) Bedrock map, Hamar 1:250.000. Geological Survey of Norway

Ødegaard H (2006) Evaluation of 2D resistivity method and digital terrain models (DTM) for planning of subsurface constructions. Norwegian University of Technology and Science, NTNU, Norwegian

Olesen O (2006) Action map for tunnel planners, central eastern part of Norway, geophysical interpretation of deep tropical weathering. Scale 1: 100.000. Geological Survey of Norway, Trondheim. Olesen O, Dehls JF, Ebbing J, Henriksen H, Kihle O, Lundin E (2007) Aeromagnetic mapping of deep-weathered fracture zones in the Oslo Region-a new tool for improved planning of tunnels. Nor J Geol 87:253-287

Olesen O, Bering D, Brønner M, Dalsegg E, Fabian K, Fredin O, Gellein J, Husteli B, Magnus C, Rønning JS, Solbakk T, 
Tønnesen JF, Øverland JA (2012) Tropical weathering in Norway, TWIN Final Report. NGU Report 2012.005: 1-188

Olesen O, Dehls JF, Ebbing J, Henriksen H, Kihle O, Lundin E (2007) Aeromagnetic mapping of deep-weatheredfracture zones in the Oslo Region - a new tool for improved planning of tunnels. Nor J Geo 87:253-287

Padget P, Brekke H (1996) Bedrock map 1:250.000. Arendal, Geological Survey of Norway

Palmstrøm A, Nilsen B, Pedersen KB, Grundt L (2003). Correct extent of site investigations for underground facilities. Project: Tunnels for the Citizens. Directorate of Public Roads (in Norwegian), Oslo, Publ No 101: 1-116. ISSN 0803-6950 http://www.vegvesen.no/_attachment/61906/binary/15128

Paterson NR, Ronka V (1971) Five years of surveying with the very low frequency electro magnetic method. Geoexploration 9:7-26

Pedersen OC (2003) Refraction seismic over the Lunner tunnel, Grualia. Geomap Report no. 221424.01: 1-5 (in Norwegian)

Reiser F, Dalsegg E, Dahlin T, Ganerød GV, Rønning JS (2009) Resistivity modelling of fracture zones and horizontal layers in bedrock. NGU Report 2009.070, 1-120. http://www.ngu.no/no/ hm/Publikasjoner/Rapporter/2009/

Reynolds JM (1997) An Introduction to Applied and Environmental Geophysics. John Wiley, England. ISBN 0-471-95555-8

Rohde JK, Skaug KH (2012) From quick clay to deep weathered bedrock; results from site investigations along Rv. 23 between Linnes and Dagslet in Lier and Røyken municipality. Proceedings, Fjellspregningskonferansen 22-23. Nov 2012, Oslo, Norway (in Norwegian)

Rønning JS (2003) Tunnels for the citizens. Subproject a, feasibility studies. Directorate of public roads, Oslo, Report Publ. No. 102: 1-66. ISSN 0803-6950 (in Norwegian). http://www.vegvesen. no/_attachment/61905/binary/15127

Rønning JS, Dalsegg E (2001) Tunnels for the citizens. Geophysical measurements at Langvatnet, Lunner, Oppland. NGU report 2001.090: 1-22 (in Norwegian). http://www.ngu.no/upload/ Publikasjoner/Rapporter/2001/2001_090.pdf
Rønning JS, Dalsegg E, Elvebakk H, Storrø G (2003) Characterization of fracture zones in bedrock using 2D resistivity. In: 9th meeting of environmental and engineering geophysics. Prague, Czech Republic, Czech Association of the Applied Geophysicists: Czech Republic P-005

Rønning JS, Olesen O, Dalsegg E, Elvebakk H, Gellein J (2007) Deep weathering in the Oslo Region. Proving and follow up investigations. NGU Report 2007.034: 1-50 (In Norwegian). http:// www.ngu.no/FileArchive/237/2007_034.pdf

Rønning JS, Dalsegg E, Elvebakk H, Ganerød GV, Heincke BH (2009a) Characterization of fracture zones in bedrock using 2D resistivity. Proceedings from 5th seminar on strait crossings, Trondheim, June 21-24, 2009: 439-444 (SINTEF/NTNU)

Rønning JS, Dalsegg E, Heincke B, Olesen O, Tønnesen JF (2009b) Geophysical measurements over the Hanekleiv, Ravnehei and Vadfoss tunnels. NGU-report 2009.040: 1-33 (in Norwegian). http:// www.ngu.no/upload/Publikasjoner/Rapporter/2009/2009_040.pdf

Seaton WJ, Burbey TJ (2002) Evaluation of two-dimensional resistivity methods in a fractured crystalline-rock terrain. J Appl Geophys 51:21-41

Solberg IL, Rønning JS, Dalsegg E, Hansen L, Rokoengen K, Sandven R (2008) Resistivity measurements as a tool for outlining quick-clay extent and valley-fill stratigraphy: a feasibility study from Buvika, central Norway. Can Geotech J 45:210-225. doi:10.1139/T07-089

Solberg IL, Hansen L, Rønning JS, Haugen ED, Dalsegg E, Tønnesen JF (2011) Combined geophysical and geotechnical approach for ground investigations and hazard zonation of a quick-clay area mid Norway. Bull Engl Geol Environ 71(1):119-133. doi:10. 1007/s10064-011-0363-x

Westerdahl H (2003) Seismic modelling of soil filled depressions in bedrock, fracture zones in bedrock and hanging cable in the sea. Tunnels for the citizens. Directorate of Public Roads Oslo, Norway, Report 32: 1-50 (in Norwegian). http://svvgw.vegve sen.no/http:/svvbibsys01.vegvesen.no/epublisher/document.asp? func $=$ show $\&$ id $=114 \&$ type $=0 \&$ service $=0$ 